\title{
Возраст и Lu-Hf изотопная систематика циркона из метапелитовых гранулитов Курско-Бесединского домена: свидетельства существования палеоархейской коры Курского блока Сарматии
}

\author{
(C) 2020 К. А. Савко ${ }^{1,2 凶}$, А. В. Самсонов ${ }^{3}$, М. В. Червяковская ${ }^{4}$, \\ Е. Х. Кориш ${ }^{1}$, А. Н. Ларионов ${ }^{5}$, Н. С. Базиков ${ }^{1}$ \\ ${ }^{1}$ Воронежский государственный университет, Университетская пл., 1, \\ 394018, Воронеж, Российская Федерация \\ ${ }^{2}$ Российский государственный геологоразведочный университет, \\ Старооскольский филиал, ул. Ленина, 14/13, 309514, Старый Оскол, Российская Федерация \\ ${ }^{3}$ Институт геологии рудных месторождений, петрографии, минералогии и геохимии \\ Российской академии наук, Старомонетный пер., 35, 119017, Москва, Российская Федерация \\ ${ }^{4}$ Институт геологии и геохимии им. А. Н. Заварицкого, Уральского отделения Российской \\ академии наук, ул. Вонсовского, 15, 620016, Екатеринбург, Российская Федерация \\ ${ }^{5}$ Центр изотопных исследований Всероссийского научно-исследовательского \\ геологического института им. А. П. Карпинского (ВСЕГЕИ), \\ Средний пр., 74, 199106, Санкт-Петербург, Российская Федерация
}

\begin{abstract}
Аннотация
Введение: В южном сегменте Восточно-Европейского кратона - Сарматии - давно известно существование палеоархейской коры на Украинском щите. В восточной части Сарматии, в Курском блоке, породы обоянского комплекса относились к раннему архею, несмотря на отсутствие прецизионных изотопных датировок абсолютного возраста. Признаки палеоархейской коры здесь фиксируются многочисленными находками пород с палеоархейской коровой предысторией по $\mathrm{Sm}-\mathrm{Nd}$ и Lu-Hf изотопным данным. Цель настоящей статьи - выявить эпизоды роста палеоархейской коры на основе изотопного U-Pb датирования и изотопной Lu-Hf систематики цирконов из метапелитовых гранулитов Курско-Бесединского домена.

Методика: Определен возраст и Lu-Hf изотопный состав циркона из метапелитовых гранулитов Курско-Бесединского домена, а также содержание в породах петрогенных, оксидов и редких элементов. Результаты и обсуждение: При изотопном датировании установлены разные значения возрастов для широких оболочек и ядер циркона. Возраст кайм составляет около 2.8 млрд лет и интерпретируется как возраст гранулитового метаморфизма. Палеоархейские возрасты установлены для всех ядер цирконов из метапелитов, причем они образуют несколько кластеров $(3535 \pm 13,3464 \pm 9$ и 3334-3384 млн лет), по-видимому, отражающих, эпизоды роста коры и указывающих на гетерогенную природу источника сноса. Хотя Lu-Hf изотопная система в цирконе демонстрирует широкие вариации изотопного состава Hf, все модельные возрасты $\mathrm{T}_{\mathrm{Hf}}(\mathrm{DM})$ являются палеоархейскими, эоархейскими и даже гадейскими. По геохимическим данным палеоархейские осадки представлены незрелыми пелитами и псаммитами, источниками сноса для которых были породы кислого состава.
\end{abstract}

Контент доступен под лицензией Creative Commons Attribution 4.0 License.

\footnotetext{
Савко Константин Аркадьевич, e-mail: ksavko@geol.vsu.ru
} 
Заключение: В строении палеоархейской коры Курско-Бесединского домена выделяется более древний фундамент, сложенный породами тоналит-трондьемит-гранодиоритовой ассоциации, на котором первоначально залегали вулканогенно-осадочные породы чехла, представленные пелитами, хемогенными железисто-кремнистыми формациями и основными вулканитами. Такая супракрустальная ассоциация предполагает формирование, вероятно, в условиях пассивной окраины. В результате метаморфической переработки около 2.8 млрд лет назад данные породы были превращены в ортогнейсы, метапелитовые и мафитовые гранулиты и породы железисто-кремнистой формации. В цирконе из метапелитов зафиксировано несколько эпизодов роста коры: 3535-3556, 3464-3472 и 3334-3384 млн лет назад. Метапелиты имеют длительную коровую предысторию, древние эоархейские и даже гадейские источники вещества. Возраст циркона 3334-3384 млн лет может быть принят как верхняя граница возраста накопления протолита метапелитов.

Ключевые слова: Курский блок, изотопная систематика, гранулиты, палеоархей

Источник финансирования: Работа поддержана проектами РФФИ № 19-05-00159 и РНФ № 16-1710283 и госзаданием ИГЕМ РАН «Петрология и минерагения магматизма внутриплитных и посторогенных обстановок: роль литосферных и астеносферных источников в формировании расплавов».

Для иитирования: Савко К. А., Самсонов А. В., Червяковская М. В., Кориш Е. Х., Ларионов А. Н., Базиков Н. С. Возраст и Lu-Hf изотопная систематика циркона из метапелитовых гранулитов Курско-Бесединского домена: свидетельства существования палеоархейской коры Курского блока Сарматии // Вестник Воронежского государственного университета. Серия: Геология. 2020. №3. С. 30-44. DOI: https://doi.org/10.17308/geology.2020.3/3007

\section{Введение}

В южном сегменте Восточно-Европейского кратона - Сарматии - давно известно существование палеоархейской коры в Приазовском блоке Украинского щита $[1,2,3$ и др.]. В восточной части Сарматии в Курском блоке породы обоянского комплекса (ранее серии) традиционно относились к раннему архею, несмотря на отсутствие прецизионных изотопных датировок абсолютного возраста. В составе обоянского комплекса по набору высоко метаморфизованных пород были выделены россошанская, донская и брянская (обоянская) ассоциации пород. Впоследствии все они, за исключением обоянской ассоциации в Курско-Бесединском домене, оказались палеопротерозойскими $[4$, $5,6]$. До настоящего времени опубликована единственная датировка палеоархейского возраста по циркону (TIMS) из плагиогнейсов Курско-Бесединского домена $-3277 \pm 33$ млн лет (скважина 3588) [7]. Тем не менее, признаки палеоархейской коры на значительной площади фиксируются многочисленными находками пород с палеоархейской коровой предысторией по $\mathrm{Sm}-\mathrm{Nd}$ и Lu-Hf изотопным данным $[4,8,9,10,11,12]$.

Цель настоящей статьи - выявить эпизоды роста палеоархейской коры Курского блока на основе изотопного $\mathrm{U}-\mathrm{Pb}$ датирования и изотопной $\mathrm{Lu}-\mathrm{Hf}$ систематики цирконов из метапелитовых гранулитов КурскоБесединского домена.

\section{Краткий обзор эволюции}

\section{раннедокембрийской коры Курского блока}

Проведенные ранее исследования позволили распознать главные эпизоды в геологической истории Курского блока и его обрамления. Около 2.8 млрд лет назад был сформирован стабильный блок архейской коры $[13,14]$. В конце архея 2.7-2.6 млрд лет назад этот блок подвергся воздействию плюма, который распознается по внутриплитному кислому и базитовому маг- матизму и, вероятно, сопряженному рифтогенезу [12, 13]. В интервале 2.60-2.45 млрд лет Курский блок был частью стабильной платформы. В морских бассейнах на пассивной континентальной окраине происходило накопление терригенных, карбонатных и железистокремнистых осадков $[13,15,16]$. В интервале $2.40-2.20$ млрд лет наступил длительный перерыв в осадконакоплении, сопровождавшийся эрозией, когда до рубежа около 2.3 млрд лет назад накапливались только континентальные отложения. Таким образом, в интервале с 2.6 до 2.2 млрд лет Курский блок представлял стабильную платформу, пенеплен с корами выветривания и осадконакоплением, включая железисто-кремнистые формации (ЖКФ), на фоне эндогенного затишья.

В период 2.2-2.06 млрд лет палеопротерозойская платформа Курского блока претерпела интенсивную эндогенную переработку, включая магматизм, рифтогенез, складчатость и метаморфизм, которые были связаны с субдукционными и коллизионными процессами в ходе эволюции обрамляющих Курский блок палеопротерозойских Волго-Донского и Ингуло-Севского орогенов $[5,6,8,17,18,19]$ (рис. 1). В ходе этих событий был сформирован структурный облик Воронежского массива.

В отличие от неоархейской и палеопротерозойской истории Курского блока, его более ранняя история изучена менее детально. Основной объем архейской коры Курского домена Сарматии представлен двумя типами геологических террейнов: Курско-Бесединской гранулит-гнейсовой (ГГО) и Михайловской гранит-зеленокаменной областями. Курско-Бесединский гранулитгнейсовый домен сложен мигматизированными ортогнейсами, которые находятся между двух протяженных палеопротерозойских рифтовых структур: ТимЯстребовской и Белгород-Михайловской (рис. 1). Области развития гранулитов выделяются на фоне общего мозаичного поля ортогнейсов интенсивными 


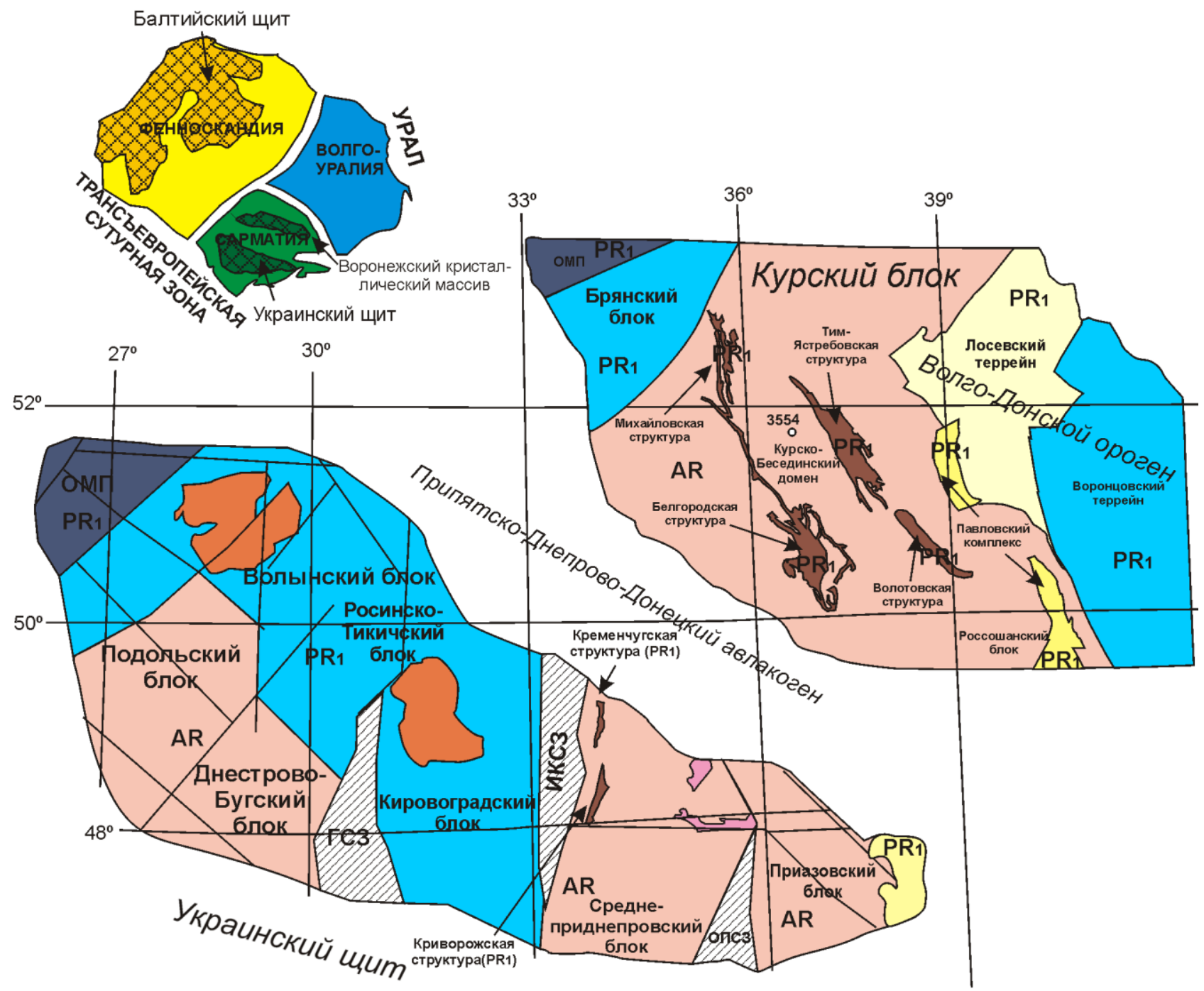

Рис. 1. Схематическая структурная карта Сарматии, составленная по [20] для Украинского щита и по собственным материалам для Воронежского кристаллического массива. Аббревиатуры: ГСЗ - Голованевская сутурная зона, ИКСЗ - Ингулец-Криворожская сутурная зона, ОПС3 - Орехово-Павлоградская сутурная зона, ОМП - Осницко-Микашевичский пояс.

[Fig. 1. A sketch map of the Sarmatia, compiled after [20] for Ukrainian Shield, and authors data (for Voronezh Crystalline Massif). Abbreviations: ГС3 - Golovanevsk Suture Zone, ИКС3 - Ingulets-Krivoy Rog Suture Zone, ОПС3 - Orekhovo-Pavlograd Suture Zone, OMП - Osnitsk-Mikashevichi Igneous Belt.]

положительными магнитными аномалиями (Ушаковские, Кувшиновские, Будановские, Бесединские и др.) эллипсовидной, серповидной и полосовидной формы и были изучены скважинами глубиной 100-600 м (рис. 2). Гранулиты представлены чередованием в разрезах скважин метапелитов, метабазитов и пород ЖКФ мощностью от 1-2 до 35 м. Архейские ЖКФ (пироксен-магнетитовые кварциты) встречаются в виде удлиненных тел, фиксируемых положительными магнитными аномалиями протяженностью до 10 км и шириной не более 100 м. Метабазиты образуют пластовые и линзовидные тела длиной от 150-200 м до 7500 м и мощностью от первых десятков до 100 м и залегают согласно с вмещающими метапелитами и ЖКФ.

Изучение реакционных структур в метапелитах и пироксен-магнетитовых кварцитах (ЖКФ) показало, что в истории Курско-Бесединской ГГО фиксируется, по крайней мере, два метаморфических события [21, 22]: M1 - UHT метаморфизм при $\mathrm{T} \geq 1000{ }^{\circ} \mathrm{C}, \mathrm{P}=10$ 11 кбар, D (глубина) $\geq 36-38$ км; М2 - метаморфизм при Т порядка $750{ }^{\circ} \mathrm{C}, \mathrm{P}=4.6-5.2$ кбар, $\mathrm{D}=16-18$ км с последующим спадом температур ниже $615{ }^{\circ} \mathrm{C}$ и давлений до 3.5 кбар. Возраст гранулитового метаморфизма M2, определенный по датированию монацита (ID TIMS) составляет 2.82 млрд лет [4, 14].

Ранее были опубликованы немногочисленные свидетельства наличия палеоархейского вещества в Курско-Бесединском домене. $\mathrm{Nd}$ модельные возрасты ортогнейсов составляют 3.64-3.49 млрд лет [8], для метапелитового гранулита - 3.42 млрд лет [4]. Кроме того, неоархейские риолиты и граниты в южном обрамлении Тим-Ястребовской структуры также характеризуются палеоархейскими $\mathrm{Nd}$ (3.29-3.61 млрд лет) модельными возрастами для пород и Нf для цирконов $[11,12]$. 


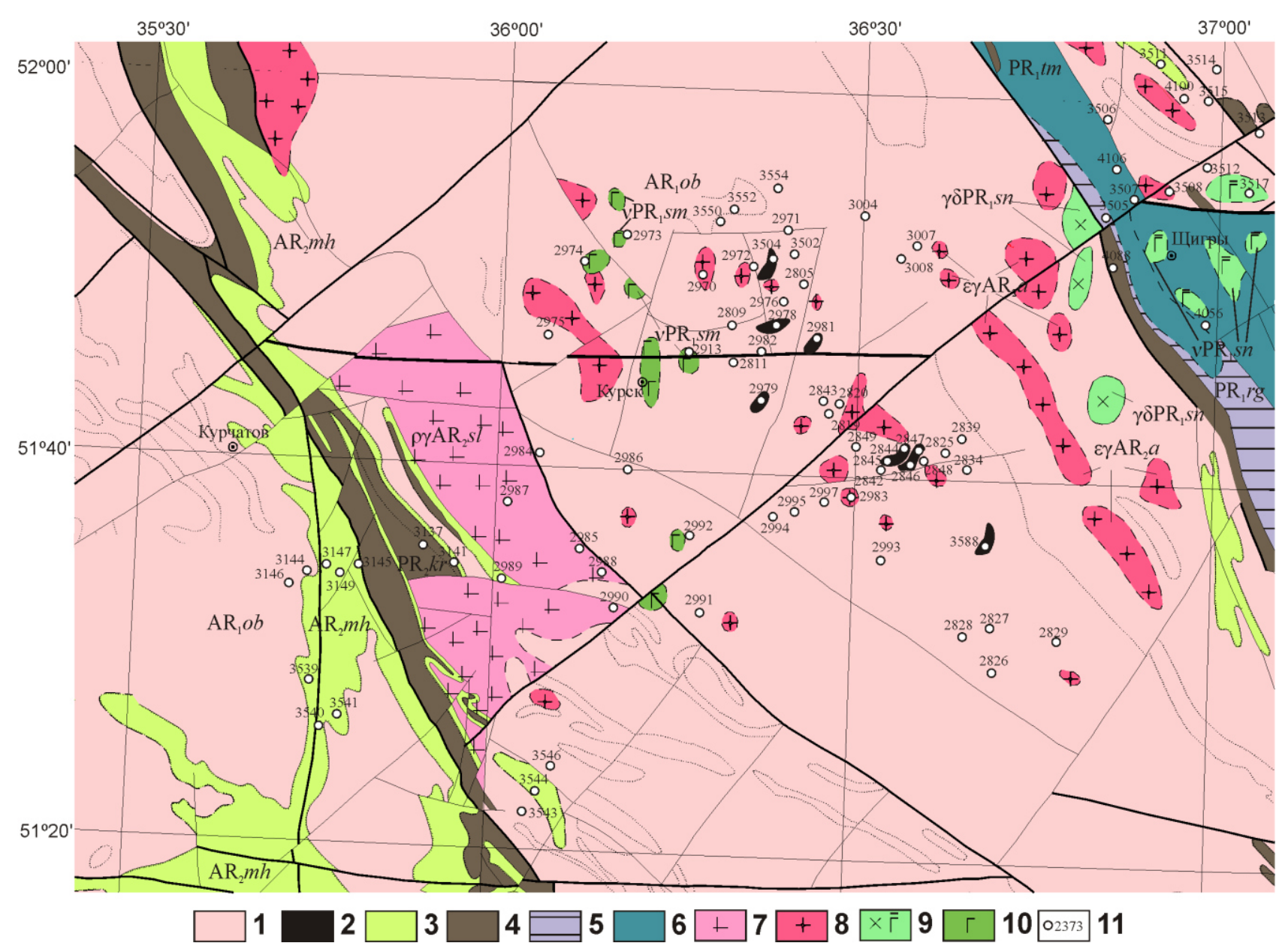

Рис. 2. Геологическая карта Курско-Бесединского домена: 1 - $\mathrm{AR}_{1} o b$ обоянский комплекс (граниты, гнейсы, мигматизированные гнейсы); 2 - $\mathrm{AR} 1 o b$ обоянский комплекс (фрагменты гранулитов); 3 - $\mathrm{AR}_{2} m h$ михайловская серия; 4 - $\mathrm{PR}_{1} k r$ курская серия; 5 - $\mathrm{PR}_{1} r g$ роговская свита; $6-\mathrm{PR}_{1} t m$ тимская свита; $7-\rho \gamma \mathrm{AR}_{2} s l$ салтыковский комплекс; $8-\varepsilon \gamma \mathrm{AR}_{2} a$ атаманский комплекс; $9-\gamma \delta v \mathrm{PR}_{1} s n$ стойлониколаевский комплекс; $10-v \mathrm{PR}_{1} s m$ смородинский комплекс; $11-$ номера скважин.

[Fig. 2. Geological map of the Kursk-Besedino Domain: $1-\mathrm{AR}_{1} o b$ Oboyan complex (granites, gneisses, migmatised gneisses); $2-\mathrm{AR}_{1} o b$ Oboyan complex (granulite fragments); $3-\mathrm{AR}_{2} m h$ Mikhailovka group; $4-\mathrm{PR}_{1} k r$ Kursk group; $5-\mathrm{PR}_{1} r g$ Rogovoe formation; $6-\mathrm{PR}_{1} t m$ Tim formation; 7 - $\rho \gamma \mathrm{AR}_{2} s l$ Saltyki complex; $8-\varepsilon \gamma \mathrm{AR}_{2} a$ Ataman complex; $9-\gamma \delta v \mathrm{PR}_{1} s n$ Stoilo-Nikolaev complex; $10-v \mathrm{PR}_{1} s m$ Smorodino complex; 11 - drillhole numbers.]

На западе они граничат с ареалами распространения пород тоналит-трондьемит-гранодиоритовой (ТТГ) ассоциации, среди которых присутствуют небольшие зеленокаменные пояса петельчатой формы [23], сложенные метаморфизованными вулканическими породами основного, реже кислого состава, метакоматиитами, терригенными метаосадочными породами, а также породами железисто-кремнистой формации. Степень метаморфизма не выше амфиболитовой фации [24]. В отличие от Курско-Бесединского домена в них не выявлена палеоархейская предыстория. Возраст ТТГ и кислых вулканитов не превышает 3.12 млрд лет, $\mathrm{Nd}$ модельные возрасты менее 3.3 млрд лет [23, 25].

\section{Аналитические методики}

Определение содержаний главных элементов в породах выполнено рентгенофлюоресцентным методом в Воронежском государственном университете, а содержаний элементов-примесей - методом ICP-MS в
Аналитическом сертификационном испытательном центре Института проблем технологии микроэлектроники и особо чистых материалов РАН (г. Черноголовка) с относительной погрешностью $3-5 \%$.

Выделение акцессорного циркона проводилось по стандартной методике с использованием тяжелых жидкостей. $\mathrm{U}-\mathrm{Th}-\mathrm{Pb}$ геохронологические исследования выполнены в ЦИИ ВСЕГЕИ (г. Санкт-Петербург) на ионном микрозонде SHRIMP II по методике [26] с использованием эталонных цирконов “91500” и “Temora". При расчетах использованы константы распада урана [27]. Поправки на нерадиогенный свинец введены по модели [28] на основе измеренных отношений ${ }^{204} \mathrm{~Pb} /{ }^{206} \mathrm{~Pb}$. Полученные результаты обработаны с помощью программы SQUID [29].

Изучение Lu-Hf-изотопного состава цирконов выполнено на многоколлекторном масс-спектрометре Neptune Plus с приставкой для лазерной абляции NWR 213 в Институте геологии и геохимии им. Академика 
А. Н. Заварицкого УрО РАН, г. Екатеринбург. Выполнена оптимизация процедуры обработки экспериментальных данных с использованием стандартов циркона Mud Tank, GJ-1 [30]. Неопределенность единичного измерения отношения ${ }^{176} \mathrm{Hf} /{ }^{177} \mathrm{Hf}$ в виде $2 \mathrm{SD}$ - в интервале $0.005-0.008 \%$, единичного определения значения $\varepsilon(\mathrm{Hf})$ в виде 2SD варьировала для перечисленных стандартов в интервале 5-9 \%. Параметры процесса лазерной абляции: плотность энергии лазерного излучения

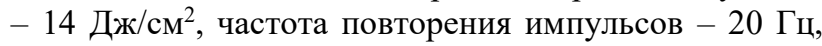
диаметр кратера - 25 мкм.

\section{Петрография и геохимия}

Метапелитовые гранулиты представлены гранатбиотитовыми, силлиманит-гранат-биотитовыми, гранат-кордиеритовыми гнейсами светло-серой и серой окраски, массивными или неяснополосчатыми, средне-крупнозернистыми. Структура гранобластовая, лепидогранобластовая, порфиробластовая. Порфиробласты сложены гранатом, достигающим до $1 \mathrm{~cm}$ в диаметре. Основные минералы породы - кварц (20$25 \%$ ), кордиерит (до 25\%) и плагиоклаз (15-20\%). В различных количествах присутствует гранат (от 10 до $25 \%$ ) и ортопироксен (10-15\%), биотит (5-20\%) и шпинель (0-10\%). Постоянно присутствует магнетит и пирит (до 3\%). Акцессорные минералы представлены цирконом, апатитом и монацитом. Основные минеральные ассоциации: Qtz+Grt+Kfs+Pl+Crd+Sil+ $\mathrm{Spl}+\mathrm{Bt}+\mathrm{Mag}$, иногда с Ilm, Рy, и Qtz+Grt+Kfs $+\mathrm{Sil}+$ $\mathrm{Opx}+\mathrm{Spl}+\mathrm{Crd}+\mathrm{Bt}+\mathrm{Py}+\mathrm{Mag}$ (рис. 3). В метапелитовых гранулитах Курско-Бесединского домена присутствуют разнообразные структуры распада полевых шпатов: антипертиты, мезопертиты и пертиты.
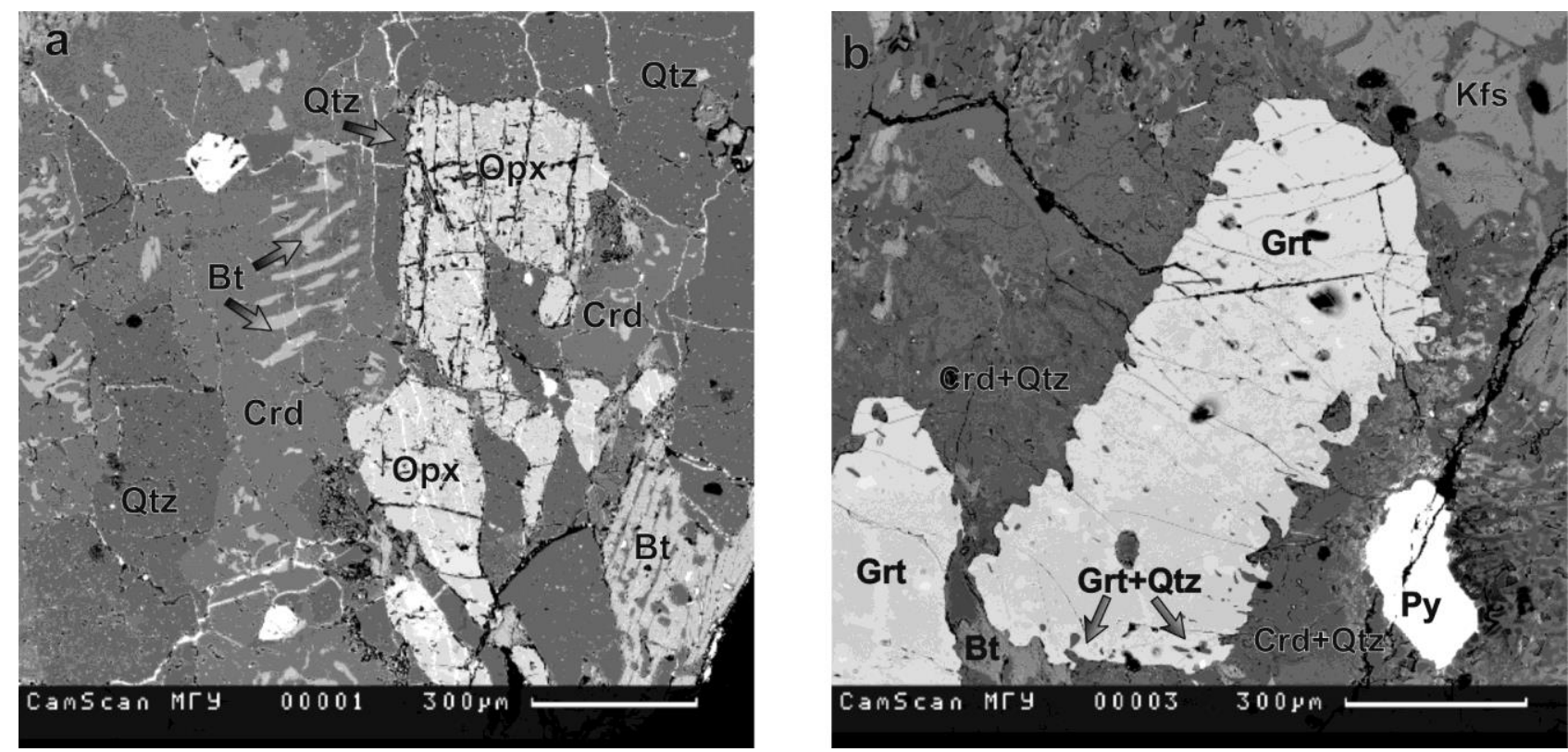

Рис. 3. Минеральные ассоциации в метапелитовых гранулитах Курско-Бесединского домена (изображения в отраженных электронах, растровый электронный микроскоп CamScan: $a$ - ортопироксен-кордиеритовый гранулит, образец 3554/224.5; $b-$ гранат-кордиеритовый гранулит, образец 3554/143.

[Fig. 3. Mineral associations in metapelite granulites from Kursk-Besedino Domain (back scattered electron images, scanning electon microscope CamSan: $a$ - orthopyroxene-cordierite granulite, sample 3554/224.5; $b$ - garnet-cordierite granulite, sample 3554/143).]

Геохимия. По содержаниям большинства петрогенных окислов метапелитовый гранулит из образца 3554/224.5 близок к среднему химическому составу архейских кратонических сланцев (average chemical compositions of Archean cratonic shales - ACS) [31]: $\mathrm{SiO}_{2}(64$ мас. \%) и $\mathrm{Al}_{2} \mathrm{O}_{3}$ (почти 17 мас. \%) с низкими значениями соотношения $\mathrm{SiO}_{2} / \mathrm{Al}_{2} \mathrm{O}_{3}=3.8$, но отличается более высокой концентрацией калия $\left(\mathrm{K}_{2} \mathrm{O}=7.45\right.$ мас. \%), резко преобладающего над натрием $\left(\mathrm{K}_{2} \mathrm{O} / \mathrm{Na}_{2} \mathrm{O}=7.8\right)$, и низкой $-\mathrm{Fe}_{2} \mathrm{O}_{3} \mathrm{t}$ (4.8 мас. \%) (табл. 1).

Метапелитовый гранулит отличается невысокими концентрациями $\mathrm{Cr}$ и Ni (55 и 49 мкг/г), $\mathrm{Sr}(24$ мкг/г), но имеет очень высокие содержания высокозарядных элементов $\mathrm{Zr}(948$ мкг/г), Nb (27.3 мкг/г), за исключением Y (34.5 мкг/г), а также Ва (3334 мкг/г) и редкозе- мельных элементов (Р3Э) ( $\mathrm{REE}=430$ мкг/г). Р3Э характеризуются высокой степенью фракционирования $\left.(\mathrm{La} / \mathrm{Yb})_{\mathrm{CN}}=16\right)$ и выраженной отрицательной $\mathrm{Eu}$ aномалией (табл. 1, рис. 4).

При сравнении с ACS метапелитовый гранулит обнаруживает близкие концентрации $\mathrm{Y}, \mathrm{Ta}$, избыток $\mathrm{Rb}$ (1.4xACS), $\mathrm{Nb}(2.4 x \mathrm{ACS})$ и REE, особенно сильный Ва (7.4xACS) и $\mathrm{Zr}$ (6.3xACS), а также дефицит $\mathrm{Sr}$ (0.4xACS), особенно резкий $\mathrm{Cr}$ и $\mathrm{Ni}(0.1 \times \mathrm{ACS}$ и $0.2 \mathrm{xACS})$. Индекс химического изменения CIA $=63$ характеризует невысокую степень выветривания пород в источнике сноса (меньше 70), что подтверждается низкой зрелостью пород, определяемой по индексу ICV (более 1.0). В метапелитовых гранулитах ICV = 1.32. Такие отложения часто устанавливаются в тектонически 
активных обстановках [32]. Обращают на себя внимание низкие содержания $\mathrm{Cr}$ и $\mathrm{Ni}$ в метаосадках по сравнению с архейскими сланцами [31], что свидетельствует об их образовании при выветривании архейских гранитоидов. Высокое содержание литофильных и высокозарядных элементов, а также РЗЭ в метапелитовых гранулитах $(\Sigma \mathrm{REE}=430$ мкг/г) и отрицательные аномалии $\mathrm{Eu}\left(\mathrm{Eu} / \mathrm{Eu}^{*}=0.62\right)$ согласуются с поступлением в область седиментации довольно высоких концентраций РЗЭ, что типично при значительном преобладании в областях размыва пород кислого состава.

По-видимому, палеоархейские осадки, представленные незрелыми пелитами, псаммитами и ЖКФ небольшой мощности (до 70 м), накапливались в морских бассейнах. Источниками сноса для них служили преимущественно породы кислого состава.

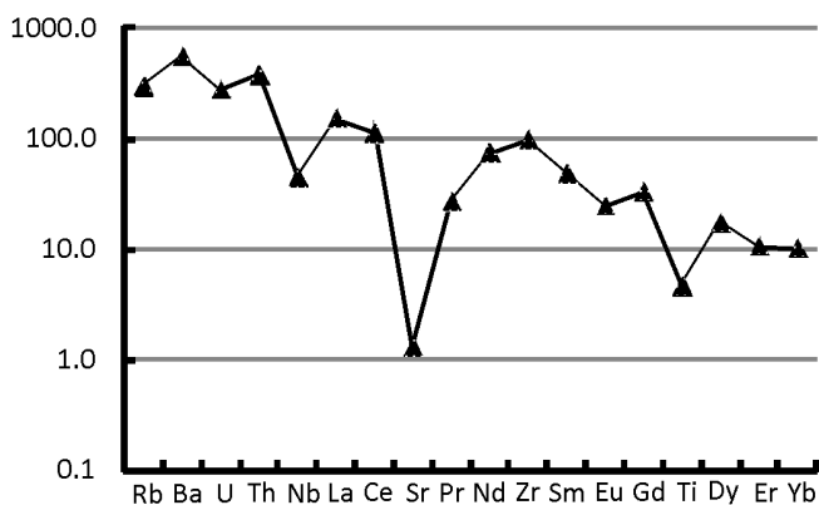

Рис. 4. Распределение редких и редкоземельных элементов в метапелитовом гранулите (образец 3554/224.5).

[Fig. 4. Chondrite-normalized trace element patterns of the metapelitic granulite (sample 3554/224.5).]

Табл. 1. Содержания пертогенных оксидов (вес. \%), редких и редкоземельных элементов (мкг/г) в метапелитовом гранулите, образец 3554/224.5

[Table 1. Major (wt. \% oxide) and trace (ppm) element contents of the Kursk Domain metapelitic granulite (sample 224.5)]

\begin{tabular}{|l|c|}
\hline $\mathrm{SiO}_{2}$ & 63.96 \\
\hline $\mathrm{TiO}_{2}$ & 0.83 \\
\hline $\mathrm{Al}_{2} \mathrm{O}_{3}$ & 16.89 \\
\hline $\mathrm{Fe}_{2} \mathrm{O}_{3}$ tot & 4.77 \\
\hline $\mathrm{MgO}$ & 3.14 \\
\hline $\mathrm{MnO}$ & 0.04 \\
\hline $\mathrm{CaO}$ & 0.35 \\
\hline $\mathrm{Na}_{2} \mathrm{O}$ & 0.96 \\
\hline $\mathrm{K}_{2} \mathrm{O}$ & 7.45 \\
\hline $\mathrm{P}_{2} \mathrm{O}_{5}$ & 0.04 \\
\hline $\begin{array}{l}\text { ПП } \\
{[\mathrm{LOI}]}\end{array}$ & 0.54 \\
\hline $\begin{array}{l}\mathrm{CyMMa} \\
{[\text { Total }]}\end{array}$ & 99.01 \\
\hline Х & 0.57 \\
\hline
\end{tabular}

\begin{tabular}{|l|c|}
\hline $\mathrm{A} / \mathrm{CNK}$ & 1.64 \\
\hline $\mathrm{CIA}$ & 62.18 \\
\hline $\mathrm{ICV}$ & 1.32 \\
\hline $\mathrm{SiO}_{2} / \mathrm{Al}_{2} \mathrm{O}_{3}$ & 3.79 \\
\hline $\mathrm{K}_{2} \mathrm{O} / \mathrm{Na}_{2} \mathrm{O}$ & 7.76 \\
\hline $\mathrm{Li}$ & 18.3 \\
\hline $\mathrm{Be}$ & 1.1 \\
\hline $\mathrm{Sc}$ & 25.0 \\
\hline $\mathrm{V}$ & 11.7 \\
\hline $\mathrm{Cr}$ & 44.8 \\
\hline $\mathrm{Ni}$ & 48.7 \\
\hline $\mathrm{Ga}$ & 28.4 \\
\hline $\mathrm{Rb}$ & 159 \\
\hline $\mathrm{Sr}$ & 23.8 \\
\hline $\mathrm{Y}$ & 34.5 \\
\hline
\end{tabular}

\begin{tabular}{|l|c|}
\hline $\mathrm{Zr}$ & 948 \\
\hline $\mathrm{Nb}$ & 27.3 \\
\hline $\mathrm{Ba}$ & 3334 \\
\hline $\mathrm{La}$ & 93.2 \\
\hline $\mathrm{Ce}$ & 178 \\
\hline $\mathrm{Pr}$ & 6.5 \\
\hline $\mathrm{Nd}$ & 88.1 \\
\hline $\mathrm{Sm}$ & 18.5 \\
\hline $\mathrm{Eu}$ & 3.6 \\
\hline $\mathrm{Gd}$ & 16.8 \\
\hline $\mathrm{Tb}$ & 2.3 \\
\hline $\mathrm{Dy}$ & 11.3 \\
\hline $\mathrm{Ho}$ & 1.8 \\
\hline $\mathrm{Er}$ & 4.4 \\
\hline $\mathrm{Tm}$ & 0.54 \\
\hline
\end{tabular}

\begin{tabular}{|l|c|}
\hline $\mathrm{Yb}$ & 4.2 \\
\hline $\mathrm{Lu}$ & 0.68 \\
\hline $\mathrm{Hf}$ & 31.3 \\
\hline $\mathrm{Ta}$ & 1.1 \\
\hline $\mathrm{Pb}$ & 36.1 \\
\hline $\mathrm{Th}$ & 30.4 \\
\hline $\mathrm{U}$ & 5.62 \\
\hline$\sum \mathrm{REE}$ & 430 \\
\hline $\mathrm{Eu} / \mathrm{Eu} *$ & 0.62 \\
\hline$(\mathrm{La} / \mathrm{Yb})_{\mathrm{cn}}$ & 15.92 \\
\hline$(\mathrm{La} / \mathrm{Sm})_{\mathrm{n}}$ & 3.25 \\
\hline$(\mathrm{Gd} / \mathrm{Yb})_{\mathrm{n}}$ & 3.31 \\
\hline
\end{tabular}

$\mathrm{X}_{\mathrm{Fe}}-$ molar Fe/(Fe $\left.+\mathrm{Mg}\right) ; \mathrm{A} / \mathrm{CNK}-$ molar $\mathrm{Al}_{2} \mathrm{O}_{3} /\left(\mathrm{CaO}+\mathrm{Na}_{2} \mathrm{O}+\mathrm{K}_{2} \mathrm{O}\right) ; \mathrm{CIA}=100 \times \mathrm{Al}_{2} \mathrm{O}_{3} /\left(\mathrm{Al}_{2} \mathrm{O}_{3}+\mathrm{CaO}+\mathrm{Na}_{2} \mathrm{O}+\mathrm{K}_{2} \mathrm{O}\right)$; $\mathrm{ICV}=\mathrm{Fe}_{2} \mathrm{O}_{3}+\mathrm{K}_{2} \mathrm{O}+\mathrm{Na}_{2} \mathrm{O}+\mathrm{CaO}+\mathrm{MgO}+\mathrm{TiO}_{2} / \mathrm{Al}_{2} \mathrm{O}_{3}$

\section{$\mathrm{U}-\mathrm{Pb}$ геохронология и Lu-Hf изотопная геохимия циркона}

Для изотопного датирования нами был выбран метапелитовый гранулит (скважина 3554, глубина 224.5 м). Детритовый циркон представлен округлыми и овальными зернами размером 100-200 мкм. В большинстве зерен наблюдаются ядра и оболочки. В КЛ в 90 \% зерен циркона сохраняются округлые и овальные ядра, выделяющиеся более светлой окраской диаметром до 50 мкм (рис. 5). Оболочки содержат более высокие концентрации урана (1005-1246 мкг/г), чем ядра (136-256 мкг/г) (табл. 2).

При изотопном датировании установлены разные значения возрастов для широких оболочек и ядер циркона. Результаты анализа оболочек образуют дискордию с верхним пересечением $2840 \pm 6$ млн лет (рис. 6). Нижнее пересечение, учитывая сложную историю цирконов, по-видимому, не имеет геологического смысла. Возрасты ядер циркона группируются в три кластера: $3535 \pm 13,3464 \pm 9$ и 3334-3384 млн лет (рис. 6; табл. 2).

Наиболее радиогенным составом Нf отличаются самые древние ядра циркона с возрастом 3535 млн лет $-\varepsilon \mathrm{Hf}_{(3535)}=+1.0-+3.3$ (табл. 3 , рис. 7). Им соответствуют палео- и эоархейские модельные возрасты $\mathrm{T}_{\mathrm{Hf}}(\mathrm{DM})^{\mathrm{c}}=3665-3812$ млн лет. Менее радиогенным составом Hf характеризуются более молодые ядра цирконов с возрастами около 3465 и 3340 млн лет $\left[\varepsilon \mathrm{Hf}_{(3465)}=-6.3-(-1.4)\right.$ и $\varepsilon \mathrm{Hf}_{(3340)}=-4.9-(-$ 2.6)]. В них установлены эоархейские модельные возрасты $\mathrm{T}_{\mathrm{Hf}}(\mathrm{DM})^{\mathrm{c}}=3755-3941$ млн лет. Наименьшие значения $\varepsilon \operatorname{Hf}(2800)=-11.0-(-15.5)$ фиксируются в метаморфических каймах циркона с возрастом около 2.8 млрд лет (рис. 7). В них преобладают очень древние гадейские модельные возрасты $\mathrm{T}_{\mathrm{Hf}}(\mathrm{DM})=3975-4337$ млн лет. 
Табл. 2 Результаты U-Pb изотопного датирования цирконов из метапелитового гранулита (образец 3554/224.5) [Table 2. SHRIMP U-Pb zircon geochronological data for the metapelitic granulite (sample 3554/224.5)]

\begin{tabular}{|c|c|c|c|c|c|c|c|c|c|c|c|c|c|c|c|c|c|c|c|}
\hline \multirow{2}{*}{$\begin{array}{c}\text { Tочка } \\
\text { [Point] } \\
21.1 \\
\end{array}$} & \multirow{2}{*}{$\begin{array}{c}\begin{array}{c}\%, \\
{ }^{206} \mathbf{P b}_{\mathrm{c}}\end{array} \\
\\
0.02 \\
\end{array}$} & \multirow{2}{*}{$\begin{array}{c}\mathbf{M k r} / \mathbf{r} \\
\mathbf{U} \\
{[\mathbf{p p m}} \\
\mathbf{U}] \\
1005 \\
\end{array}$} & \multirow{2}{*}{$\begin{array}{c}\text { Mkr/r, } \\
\text { Th } \\
\text { [ppm } \\
\text { Th] }\end{array}$} & \multirow{2}{*}{$\begin{array}{r}{ }^{232} \mathbf{T h} \\
{ }^{238} \mathbf{U} \\
0.05 \\
\end{array}$} & \multirow{2}{*}{$\begin{array}{c}\begin{array}{c}\mathrm{MKr} / \mathbf{r}, \\
{ }^{206} \mathbf{P b}^{*} \\
{\left[\mathbf{p p m}^{*}\right.}\end{array} \\
\left.{ }^{206} \mathbf{P b}^{*}\right]\end{array}$} & \multicolumn{2}{|c|}{$\begin{array}{c}(1)^{206} \mathbf{P b} /{ }^{238} \mathrm{U} \\
\text { возраст } \\
\text { (млн. лет) } \\
{[(\mathbf{1})} \\
{ }^{206} \mathrm{~Pb} /{ }^{238} \mathrm{U} \\
\text { age (Ma)] }\end{array}$} & \multicolumn{2}{|c|}{$\begin{array}{c}(1)^{207} \mathrm{~Pb} /{ }^{206} \mathrm{~Pb} \\
\text { возраст (млн. } \\
\text { лет) } \\
{\left[(1){ }^{207} \mathrm{~Pb} /{ }^{206} \mathrm{~Pb}\right.} \\
\text { age (Ma)] }\end{array}$} & \multirow{2}{*}{\begin{tabular}{|c|} 
D \\
$(\%)$ \\
4 \\
\end{tabular}} & \multirow{2}{*}{$\begin{array}{c}{ }^{(\mathbf{1})^{206}} \mathbf{P b}^{\mathbf{2 3}} \mathbf{U} / \\
1.904 \\
\end{array}$} & \multirow{2}{*}{$\begin{array}{l} \pm \% \\
2.1\end{array}$} & \multirow{2}{*}{$\begin{array}{c}{ }_{{ }^{206} \mathbf{P b}^{*}}^{\left(\mathbf{1} \mathbf{P b}^{207} \mathbf{~}^{\star}\right.} \\
0.19974\end{array}$} & \multirow{2}{*}{$\begin{array}{l} \pm \% \\
0.26\end{array}$} & \multirow{2}{*}{$\begin{aligned}{ }^{\left(\mathbf{P}^{235} \mathbf{U}\right.} \mathbf{\mathbf { 2 0 7 }} \mathbf{b} \\
14.46\end{aligned}$} & \multirow{2}{*}{$\begin{array}{l} \pm \% \\
2.1 \\
\end{array}$} & \multirow{2}{*}{$\begin{array}{c}{ }^{(\mathbf{1})^{206} \mathbf{2 3 8} \mathbf{P b}^{*}} \\
0.525\end{array}$} & \multirow{2}{*}{$\begin{array}{l} \pm \% \\
2.1\end{array}$} & \multirow[t]{2}{*}{ 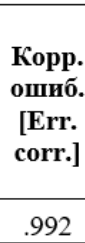 } \\
\hline & & & & & & 2721 & 46 & 2824 & \pm 4.2 & & & & & & & & & & \\
\hline 21.1re & 0.00 & 750 & 46 & 0.06 & 323 & 2619 & 45 & 2827 & \pm 11 & 8 & 1.995 & 2.1 & 0.2 & 0.68 & 13.82 & 2.2 & 0.501 & 2.1 & .951 \\
\hline 21.1re2 & 0.00 & 1318 & 45 & 0.04 & 616 & 2800 & 47 & 2827 & \pm 6.4 & 1 & 1.838 & 2.1 & 0.20015 & 0.39 & 15.01 & 2.1 & 0.544 & 2.1 & .983 \\
\hline 14.1 & 0.00 & 1273 & 25 & 0.02 & 603 & 2833 & 47 & 2828 & \pm 8.3 & 0 & 1.812 & 2.1 & 0.2002 & 0.51 & 15.23 & 2.1 & 0.552 & 2.1 & .971 \\
\hline 6.1 & 0.00 & 1339 & 38 & 0.03 & 640 & 2851 & 48 & 2833 & \pm 7.6 & -1 & 1.798 & 2.1 & 0.20084 & 0.47 & 15.4 & 2.1 & 0.556 & 2.1 & .975 \\
\hline 4.1 & 0.01 & 1283 & 41 & 0.03 & 594 & 2780 & 46 & 2836 & \pm 3.7 & 2 & 1.855 & 2.1 & 0.20126 & 0.23 & 14.96 & 2.1 & 0.539 & 2.1 & .994 \\
\hline 19.1 & 0.01 & 1016 & 17 & 0.02 & 465 & 2755 & 46 & 2836 & \pm 4.2 & 3 & 1.875 & 2.1 & 0.20116 & 0.26 & 14.79 & 2.1 & 0.533 & 2.1 & .992 \\
\hline 2.1 & 0.01 & 1056 & 17 & 0.02 & 491 & 2790 & 47 & 2840 & \pm 6.2 & 2 & 1.847 & 2.1 & 0.20175 & 0.38 & 15.06 & 2.1 & 0.542 & 2.1 & .983 \\
\hline 17.1 & 0.01 & 1223 & 31 & 0.03 & 581 & 2838 & 47 & 2846 & \pm 3.8 & 0 & 1.808 & 2.1 & 0.20243 & 0.23 & 15.44 & 2.1 & 0.553 & 2.1 & .994 \\
\hline 8.1 & 0.00 & 2146 & 28 & 0.01 & 1030 & 2855 & 47 & 2849 & \pm 3 & 0 & 1.794 & 2 & 0.2028 & 0.18 & 15.58 & 2.1 & 0.557 & 2 & .996 \\
\hline 10.1 & 0.01 & 1264 & 20 & 0.02 & 589 & 2794 & 47 & 2850 & \pm 3.8 & 2 & 1.843 & 2.1 & 0.20298 & 0.24 & 15.19 & 2.1 & 0.543 & 2.1 & .993 \\
\hline 12.1 & 0.01 & 1290 & 47 & 0.04 & 544 & 2573 & 44 & 2857 & \pm 7.6 & 11 & 2.039 & 2.1 & 0.20386 & 0.47 & 13.79 & 2.1 & 0.49 & 2.1 & .976 \\
\hline 3.1 & 0.04 & 266 & 110 & 0.43 & 152 & 3285 & 55 & 3334 & \pm 9.6 & 1 & 1.505 & 2.1 & 0.2749 & 0.61 & 25.19 & 2.2 & 0.665 & 2.1 & .961 \\
\hline 1.1 & 0.03 & 175 & 99 & 0.59 & 96.7 & 3204 & 55 & 3339 & \pm 7.5 & 4 & 1.553 & 2.2 & 0.2757 & 0.48 & 24.48 & 2.2 & 0.644 & 2.2 & .976 \\
\hline 18.1 & 0.03 & 140 & 75 & 0.55 & 80 & 3288 & 56 & 3367 & \pm 8.2 & 2 & 1.503 & 2.2 & 0.2808 & 0.52 & 25.76 & 2.2 & 0.665 & 2.2 & .972 \\
\hline 9.1 & 0.04 & 159 & 82 & 0.54 & 87.4 & 3194 & 54 & 3410 & \pm 11 & 7 & 1.559 & 2.2 & 0.2885 & 0.71 & 25.51 & 2.3 & 0.641 & 2.2 & .950 \\
\hline 15.1 & 0.00 & 130 & 71 & 0.56 & 75.5 & 3331 & 58 & 3459 & \pm 8.3 & 4 & 1.478 & 2.2 & 0.2979 & 0.54 & 27.79 & 2.3 & 0.677 & 2.2 & .973 \\
\hline 5.1 & 0.02 & 153 & 79 & 0.53 & 90.8 & 3393 & 58 & 3466 & \pm 7.6 & 2 & 1.443 & 2.2 & 0.2992 & 0.49 & 28.58 & 2.3 & 0.693 & 2.2 & .976 \\
\hline 13.1 & 0.03 & 151 & 75 & 0.51 & 85.9 & 3283 & 56 & 3466 & \pm 24 & 6 & 1.506 & 2.2 & 0.2992 & 1.5 & 27.4 & 2.6 & 0.664 & 2.2 & .817 \\
\hline 11.1 & 0.04 & 136 & 68 & 0.52 & 81.2 & 3399 & 57 & 3467 & \pm 8.3 & 2 & 1.44 & 2.2 & 0.2994 & 0.54 & 28.66 & 2.2 & 0.694 & 2.2 & .971 \\
\hline 20.1 & 0.03 & 138 & 79 & 0.59 & 85.1 & 3492 & 60 & 3536 & \pm 16 & 1 & 1.391 & 2.2 & 0.3131 & 1.1 & 31.03 & 2.5 & 0.719 & 2.2 & .901 \\
\hline 16.1 & 0.03 & 151 & 85 & 0.58 & 96.4 & 3586 & 59 & 3535 & \pm 7.2 & -1 & 1.344 & 2.2 & 0.3127 & 0.46 & 32.09 & 2.2 & 0.744 & 2.2 & .978 \\
\hline \multicolumn{20}{|c|}{$\begin{array}{l}\text { Примечания: ошибки } 1 \sigma . \mathrm{Pb}_{\mathrm{c}} \text { п } \mathrm{Pb} * \text { - первичный и радиогенный свинец, соответственно. Ошшбка в стандартной калнбровке } 0.21-0.39 \% \text {. (1) Первичный } \mathrm{Pb} \text { скорректирован на } \\
\text { измеренный }{ }^{204 \mathrm{~Pb}} \mathrm{D}, \% \text { - процент дискордантности. } \\
\text { [Errors are } 1 \sigma . \mathrm{Pbc} \text { and } \mathrm{Pb}^{*} \text { - common and radiogenic lead, respectively. Standart calibration error is } 0.21-0.39 \% \text {. (1) Common } \mathrm{Pb} \text { corrected by measured } 204 \mathrm{~Pb} \text {. } \mathrm{D} \text {, \% - percent of } \\
\text { discordance.] }\end{array}$} \\
\hline
\end{tabular}




\begin{tabular}{|c|c|c|c|c|c|c|c|c|c|c|c|c|c|}
\hline \multicolumn{14}{|c|}{$\begin{array}{l}\text { Табл. 3. Lu-Hf изотопный состав циркона из миетапелитового гранулита (образец } 3554 / 224.5) \\
\text { [Table 3. Lu-Hf isotope compositions of zircon from the metapelitic granulite (sample 3554/224.5)] }\end{array}$} \\
\hline $\begin{array}{l}\text { Tочка } \\
\text { [Spot] }\end{array}$ & 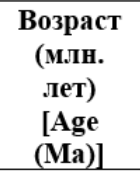 & ${ }^{176} \mathbf{Y b} / \mathbf{b}^{177} \mathbf{H f}$ & $\pm 2 \sigma$ & ${ }^{176} \mathbf{L u} \mathbf{u}^{1777} \mathbf{H f}$ & $\pm 2 \sigma$ & ${ }^{176} \mathrm{Hf} /{ }^{177} \mathbf{H f}$ & $\pm 2 \sigma$ & ${ }^{178} \mathbf{H f} /{ }^{177} \mathbf{H f}$ & $\pm 2 \sigma$ & $\left({ }^{176} \mathbf{H f} /{ }^{177} \mathbf{H}\right) \mathbf{i}$ & $\varepsilon_{H f}(t)$ & $\pm 2 \sigma$ & ${ }^{*} \mathbf{T}_{\mathrm{DM}}{ }^{\mathrm{C}}$ \\
\hline 16.1 & 3535 & 0.064552 & 0.004035 & 0.001759 & 0.000054 & 0.280720 & 0.000054 & 1.467458 & 0.000155 & 0.280600 & 3.3 & 1.9 & 3665 \\
\hline 20.1 & 3535 & 0.066371 & 0.002222 & 0.001876 & 0.000067 & 0.280663 & 0.000067 & 1.467068 & 0.000132 & 0.280535 & 1.0 & 2.4 & 3812 \\
\hline 5.1 & 3464 & 0.071635 & 0.001314 & 0.001970 & 0.000053 & 0.280507 & 0.000053 & 1.467294 & 0.000173 & 0.280376 & -6.3 & 1.8 & 4175 \\
\hline 11.1 & 3464 & 0.080754 & 0.001465 & 0.002284 & 0.000053 & 0.280635 & 0.000053 & 1.467317 & 0.000084 & 0.280483 & -2.6 & 1.9 & 3941 \\
\hline 13.1 & 3464 & 0.066343 & 0.001833 & 0.001882 & 0.000057 & 0.280606 & 0.000057 & 1.467212 & 0.000127 & 0.280481 & -2.6 & 2.0 & 3939 \\
\hline 15.1 & 3464 & 0.057256 & 0.003511 & 0.001677 & 0.000049 & 0.280625 & 0.000049 & 1.467210 & 0.000091 & 0.280513 & -1.4 & 1.6 & 3864 \\
\hline 3.1 & 3340 & 0.056852 & 0.001740 & 0.001519 & 0.000048 & 0.280622 & 0.000048 & 1.467307 & 0.000092 & 0.280524 & -4.0 & 1.7 & 3846 \\
\hline 7.1 & 3340 & 0.046310 & 0.002731 & 0.001223 & 0.000038 & 0.280642 & 0.000038 & 1.467368 & 0.000091 & 0.280564 & -2.6 & 1.3 & 3755 \\
\hline 18.1 & 3340 & 0.071954 & 0.001861 & 0.001823 & 0.000053 & 0.280615 & 0.000053 & 1.467130 & 0.000118 & 0.280498 & -4.9 & 1.9 & 3910 \\
\hline 4.1. & 2840 & 0.075945 & 0.000784 & 0.002207 & 0.000084 & 0.280673 & 0.000084 & 1.467261 & 0.000151 & 0.280553 & -14.6 & 3.0 & 4220 \\
\hline 6.1 & 2840 & 0.064306 & 0.000635 & 0.001855 & 0.000046 & 0.280757 & 0.000046 & 1.467205 & 0.000088 & 0.280656 & -11.0 & 1.6 & 3975 \\
\hline 8.1 & 2840 & 0.073559 & 0.000873 & 0.002187 & 0.000056 & 0.280725 & 0.000056 & 1.466976 & 0.000130 & 0.280606 & -12.7 & 2.0 & 4099 \\
\hline 14.1 & 2840 & 0.117335 & 0.001533 & 0.003682 & 0.000083 & 0.280728 & 0.000083 & 1.467258 & 0.000156 & 0.280528 & -15.5 & 3.0 & 4337 \\
\hline 21.1 & 2840 & 0.076777 & 0.000623 & 0.002182 & 0.000061 & 0.280705 & 0.000061 & 1.466828 & 0.000136 & 0.280587 & -13.4 & 2.1 & 4143 \\
\hline 21.1re & 2840 & 0.078688 & 0.000459 & 0.002250 & 0.000044 & 0.280779 & 0.000044 & 1.467002 & 0.000103 & 0.280656 & -11.0 & 1.6 & 3988 \\
\hline 21.1re2 & 2840 & 0.076821 & 0.001580 & 0.002396 & 0.000069 & 0.280725 & 0.000069 & 1.467067 & 0.000182 & 0.280595 & -13.1 & 2.5 & 4132 \\
\hline 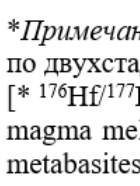 & первичнс & le contine & rrust form & $\begin{array}{ll}\mathrm{If} / 177 \mathrm{Hf}_{\mathrm{i}} \mathrm{pac} \\
.015, \mathrm{ocHOI}\end{array}$ & $\begin{array}{l}\text { ано с исп } \\
\text { рй на вып }\end{array}$ & $\begin{array}{l}\text { is the } m \\
\text { the mod }\end{array}$ & e of the & $\begin{array}{c}\text { e calcula } \\
\text { calculat }\end{array}$ & $\begin{array}{l}\text { om the to } \\
\text { ing into }\end{array}$ & $\begin{array}{l}\text { модельный в } \\
\text { ванной из деп } \\
\text { ge model usin } \\
\text { int the magma }\end{array}$ & $\begin{array}{l}\text { T исто } \\
\text { osarHo } \\
\text { und } \\
\text { ung fror }\end{array}$ & $\begin{array}{l}\text { paccu } \\
\text { run. } \\
5, \text { bas }\end{array}$ & $\begin{array}{l}\text { ганный } \\
\text { on the } \\
\text { ntle for }\end{array}$ \\
\hline
\end{tabular}




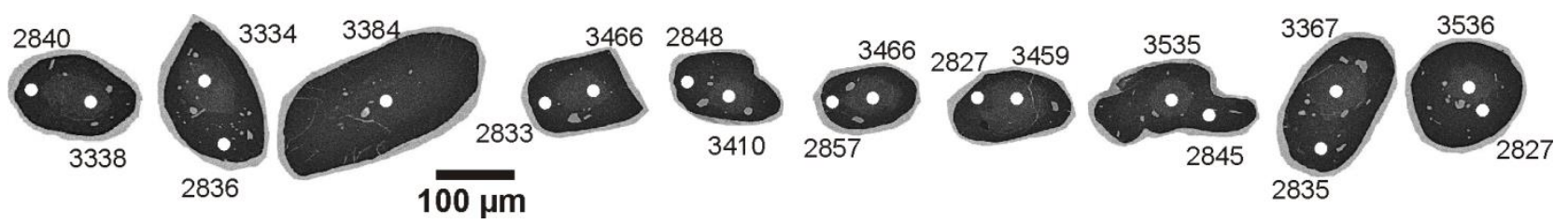

Рис. 5. КЛ-Изображения зерен циркона с точками определения изотопного ${ }^{207} \mathrm{~Pb} /{ }^{206} \mathrm{~Pb}$ возраста (образец $3554 / 224.5$ ).

[Fig. 5. Cathodoluminescence images of zircon grains. The SHRIMP spot locations are labeled with the approximate $\operatorname{spot}^{207} \mathrm{~Pb} /{ }^{206} \mathrm{~Pb}$ age.]
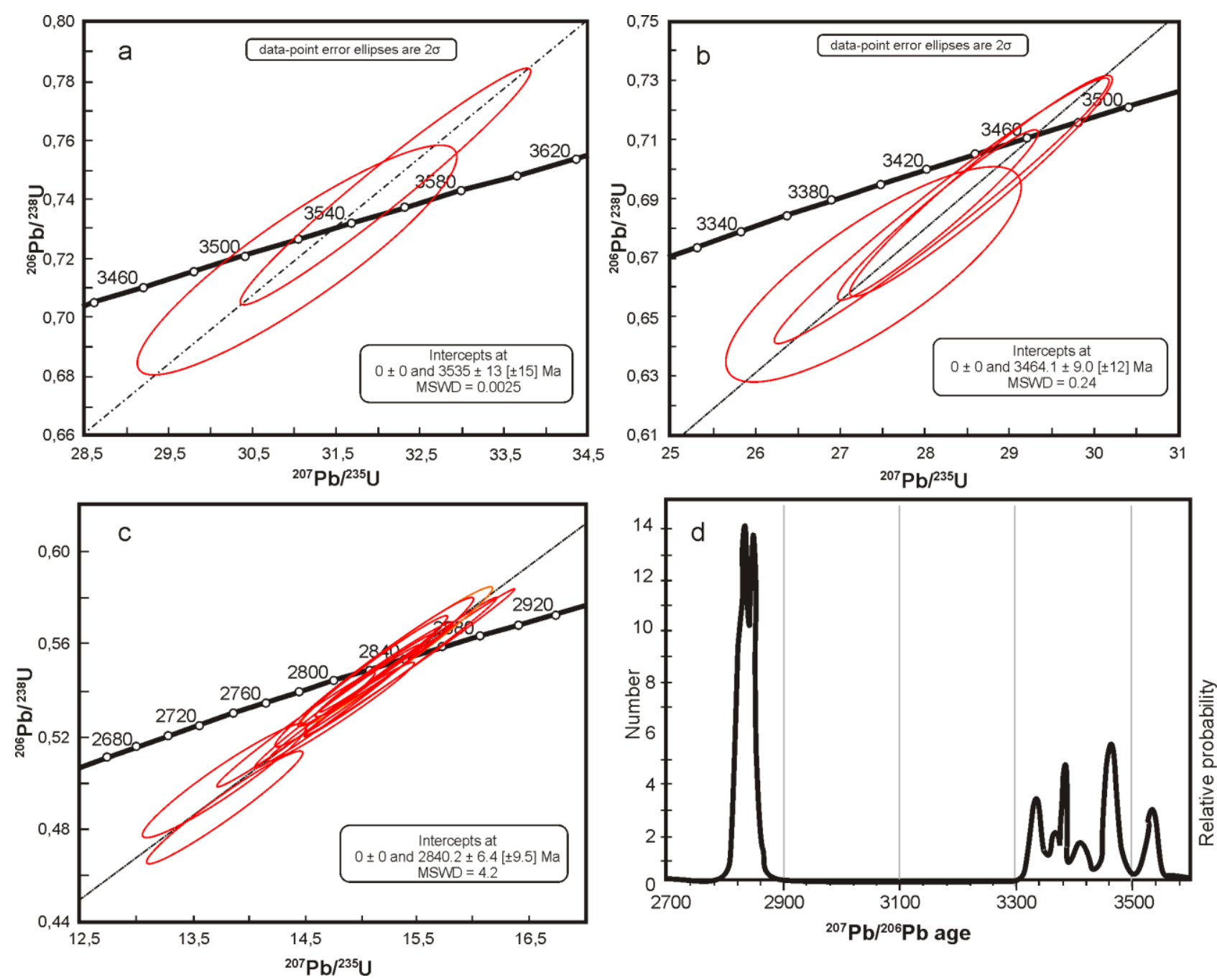

Рис. 6. Результаты изотопного датирования циркона из гранулитового метапелита, проба 3554/224.5.

[Fig. 6. The results of U-Pb SIMS analyses of zircons from the granulitic metapelite (sample 3554/224.5).]

\section{Обсуждение результатов}

Согласно проведенным исследованиям, протолиты метапелитовых пород Курско-Бесединского домена представляют собой фрагмент палеоархейской коры. Изотопное датирование циркона показало, что метапелиты претерпели известное высокотемпературное метаморфическое событие с возрастом около 2.8 млрд лет. Оно проявлено в метаморфических каймах цирконов. До метаморфического эпизода 2.82 млрд лет назад с параметрами $\mathrm{T}=750^{\circ} \mathrm{C}$ и $\mathrm{P}=4.6-5.2$ кбар в мезоархее (?) было еще одно очень высокотемпературное метаморфическое событие $\left(\mathrm{T} \geq 1000^{\circ} \mathrm{C}\right.$ и $\mathrm{P}=10$-11 кбар), свидетельством которого являются только пироксены со структурами распадов твердых растворов в ЖКФ [22] и полевые шпаты в метапелитах [33]. Возможно, это метаморфическое событие отражало раннюю кратонизацию Курско-Бесединского гранулит-гнейсового домена.

Палеоархейские возрасты установлены для всех ядер цирконов из метапелитов, причем они образуют несколько кластеров $(3535 \pm 13,3464 \pm 9$ и 3334-3384 млн лет), по-видимому, отражающих эпизоды роста коры и указывающих на гетерогенную природу источника сноса. Первичный изотопный состав неодима в метапелитах и модельные возрасты свидетельствуют о палеоархейских коровых источниках [4]. Для пород 


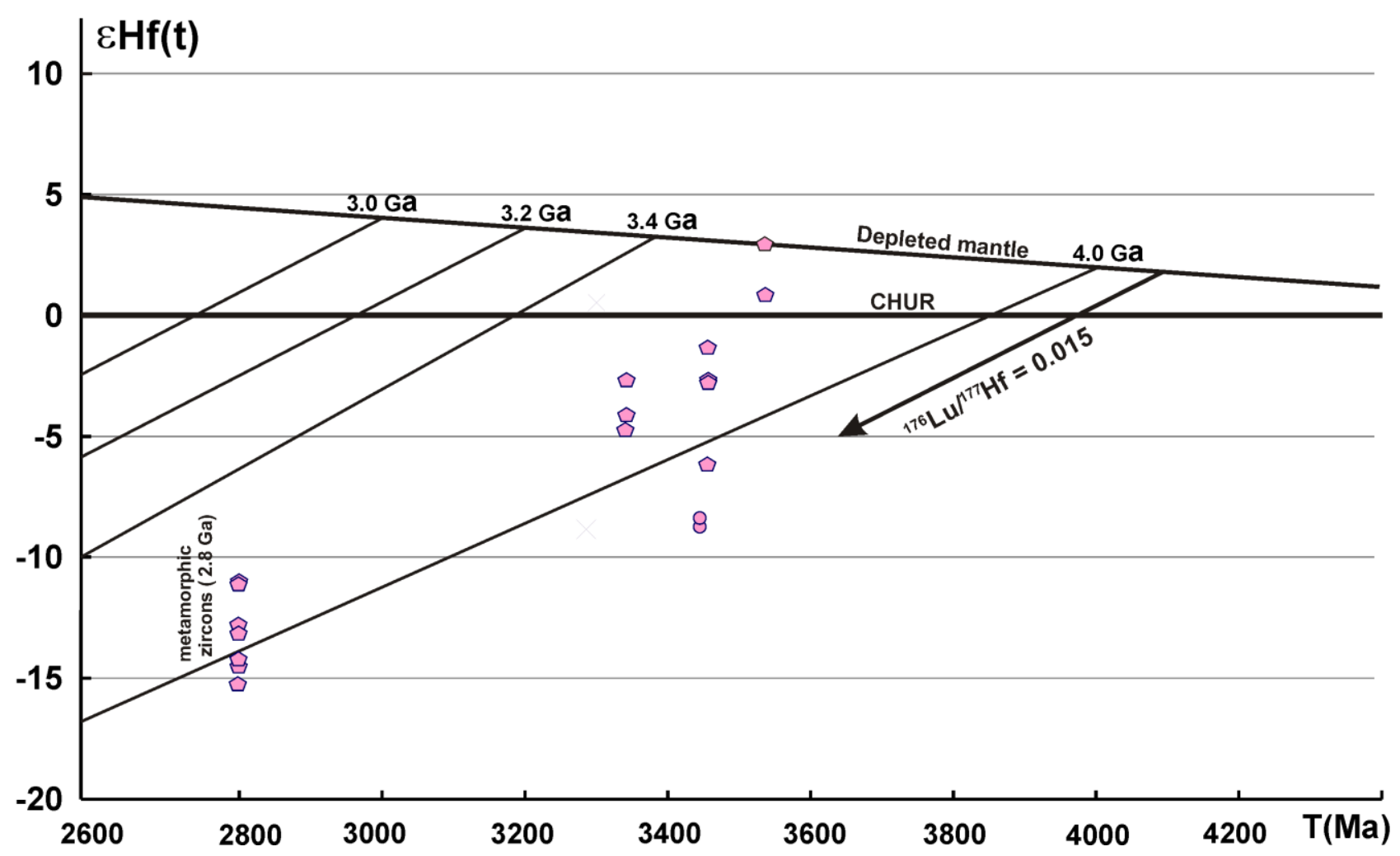

Рис. 7. Диаграмма $\varepsilon \mathrm{Hf}(\mathrm{t})$ - Т для циркона из метапелитового гранулита, проба 3554/224.5.

[Fig. 7. Plots of $\varepsilon \mathrm{Hf}(\mathrm{t})$ values versus zircon ages for the zircon grains from the granulitic metapelite (sample 3554/224.5).]

гранулит-гнейсовой области также характерен широкий диапазон отрицательных значений $\varepsilon(\mathrm{T}) \mathrm{Hf}$. Хотя Lu-Hf изотопная система в цирконе демонстрирует широкие вариации изотопного состава гафния в метапелитовых гранулитах, все модельные возрасты THf(DM) очень древние - палеоархейские, эоархейские и даже гадейские (табл. 3 , рис. 7).

Историю формирования дометаморфических протолитов пород Курско-Бесединского домена можно обсуждать на основании полученных геохронологических и изотопно-геохимических данных. Три возрастных кластера палеоархейского циркона в метапелитовых гранулитах $3535 \pm 13,3464 \pm 9$ и 3334-3384 млн лет, имеющие также разный изотопный состав Нf (рис. 6, 7), могут фиксировать, соответственно, возрасты магматического протолита этих пород и его ранней переработки. Возраст циркона третьей, более молодой, группы служит ограничением времени накопления протолита метапелитов.

Для ЖКФ Курско-Бесединского домена мы не располагаем геохронологическими или изотопными данными, которые позволили бы оценить возраст их протолитов. Проведенные ранее геохимические исследования показали контаминацию их детритовым материалом обогащенность $\mathrm{Cr}, \mathrm{Ni}$, что характерно железистых формаций типа Алгома [15].

Таким образом, в строении палеоархейской коры выделяется более древний фундамент, который был сложен ТТГ, на котором залегали вулканогенно-оса- дочные породы чехла, представленные пелитами, хемогенными ЖКФ и базитовыми силлами. Такая ассоциация вулканогенно-осадочных пород позволяет предположить, что ее формирование происходило в обстановке пассивной окраины.

\section{Выводы}

Полученные результаты изотопного изучения метапелитовых гранулитов архейского основания Курского-Бесединского Домена Сарматии позволяют сформулировать следующие выводы.

1. Палеоархейское ядро Курского блока состоит из Курско-Бесединского гранулит-гнейсового домена, сложенного ортогнейсами (ТТГ), метапелитовыми и мафитовыми гранулитами и ЖКФ.

2. В строении палеоархейской коры выделяется более древний фундамент, сложенный ТТГ (оротогнейсы), на котором залегали вулканогенно-осадочные породы чехла, представленные пелитами, хемогенными ЖКФ и основными вулканитами.

3. Палеоархейские осадки, представленные незрелыми пелитами, псаммитами и ЖКФ небольшой мощности, накапливались в морских бассейнах. Формирование палеоархейского осадочного чехла, вероятно, происходило в условиях пассивной окраины. Источниками сноса для терригенных пород служили преимущественно породы кислого состава. 4. В результате метаморфической переработки около 2.8 млрд лет назад они были превращены в ортогнейсы, метапелитовые и мафитовые гранулиты и 
ЖКФ Курско-Бесединского гранулит-гнейсового домена.

По результатам изотопного датирования цирконов в метапелитовых гранулитах Курско-Бесединского домена зафиксировано несколько эпизодов роста коры: 3535-3556, 3464-3472 и 3334-3384 млн лет. Они имеют длительную коровую предысторию, древние эоархейские и даже гадейские источники вещества. Возраст циркона 3334-3384 млн лет может быть принят как верхняя граница возраста накопления протолита метапелитов.

Конфликт интересов. Авторы декларируют отсутствие явных и потенциальных конфликтов интересов, связанных с публикацией настоящей статьи.

\section{ЛИТЕРАТУРА}

1. Щербак Н. П., Артеменко Г. В., Лесная И. М., Пономаренко А. Н. Геохронология раннего докембрия Украинского щита. Архей. Киев, Наукова думка, 2005. 243 с.

2. Bibikova E., Claesson S., Fedotova A., Artemenko G., Ilyinsky L. Early Archean crust of the Middle Dnepr and Azov Domains, Ukrainian shield - evidence from ages of detrital zircons in Mesoarchean greenstone belts // American Journal of Science. 2010. V. 310. pp. 1595-1622. DOI: $10.2475 / 10.2010 .13$

3. Claesson S., Artemenko G., Bogdanova S., Shumlyanskyy L. Archean Crustal Evolution in the Ukrainian Shield // Earth's oldest rocks, second edition. Eds: Martin J. van Kranendonk, Vickie Bennett, Elis Hoffmann. Amsterdam, Elsevier, 2018. pp. 837854. DOI: 10.1016/B978-0-444-63901-1.00033-2

4. Савко К. А., Котов А. Б., Сальникова Е. Б., Кориш Е. Х., Пилюгин С. М., Артеменко Г. В., Кориковский С. П. Возраст метаморфизма гранулитовых комплексов Воронежского кристаллического массива: результаты U-Pb геохронологических исследований монацита // Докл. АН. 2010. Т. 435. № 5. C. 647-652. URL: https://www.elibrary.ru/item.asp?id=15538654 (дата обращения: 31.08.2020).

5. Бибикова Е. В., Богданова С. В., Горбачев Р., Клаэссон С., Кирнозова Т. И. Изотопный возраст, природа и структура докембрийской коры в Беларуси // Стратиграфия. Геол. коррелячия. 1995. Т. 1. № 6. С. 68-78.

6. Terentiev R. A., Savko K. A., Santosh M., Petrakova M. E., Korish E. H. Paleoproterozoic granitoids of the Don terrane, EastSarmatian Orogen: age, magma source and tectonic implications // Precambrian Research. 2020. V. 346. 105790. DOI: 10.1016/j.precamres.2020.105790

7. Артеменко Г. В., Швайка И. А., Татаринова Е. А. Палеоархейский возраст ультраметаморфических плагиогранитов Курско-Бесединского блока (Воронежский кристаллический массив) // Геол. Журн. 2006. № 1. С. 84-87.

8. Щипанский А. А., Самсонов А. В., Петрова А. Ю., Ларионова Ю. О. Геодинамика восточной окраины Сарматии в палеопротерозое // Геотектоника. 2007. № 1. С. 43-70. URL: https://www.elibrary.ru/item.asp?id=9462648 (дата обращения: 31.08.2020).

9. Кориш Е. Х., Савко К. А., Самсонов А. В., Червяковская М. В. Палеопротерозойские диориты Троснянского массива Курского блока Сарматии: U-Pb возраст, изотопная систематика и источники расплавов // Вестник Воронежского государственного университета. Серия: Геология. 2020. № 1. С. 87-99. DOI: 10.17308/geology.2020.1/2517
10. Савко К. А., Самсонов А. В., Базиков Н. С., Козлова Е. Н. Палеопротерозойские гранитоиды Тим-Ястребовской структуры Воронежского кристаллического массива: геохимия, геохронология и источники расплавов // Вестник Воронежского государственного университета. Серия: Геология. 2014. № 2. C. 56-78. URL: http://www.vestnik.vsu.ru/pdf/heologia/2014/02/2014-02-09.pdf (дата обращения: 31.08.2020).

11. Савко К. А., Холина Н. В., Самсонов А. В., Кориш Е. Х., Червяковская М. В., Базиков Н. С., Ларионов А. Н. Петротип неоархейского атаманского комплекса гранитов Курского блока Сарматии: геохимия, геохронология, изотопная систематика // Вестник Воронежского государственного университета. Серия: Геология. 2020. № 2. С. 20-43. DOI: 10.17308/geology.2020.2/2857

12. Savko K. A., Samsonov A. V., Kholina N. V., Larionov A. N., Zaitseva M. V., Korish E. H., Bazikov N. S., Terentiev R. A. 2.6 Ga high-Si rhyolites and granites in the Kursk Domain, Eastern Sarmatia: Petrology and application for the Archaean palaeocontinental correlations // Precambrian Research. 2019. V. 322. pp. 170-192. DOI: 10.1016/j.precamres.2019.01.006

13. Савко К. А., Самсонов А. В., Холин В. М., Базиков Н. С. Мегаблок Сарматия как осколок суперкратона Ваалбара: корреляция геологических событий на границе архея и палеопротерозоя // Стратиграфия. Геол. корреляиия. 2017. Т. 25. № 2. C. 3-26. DOI: 10.7868/S0869592X17020065

14. Savko K. A., Samsonov A. V., Kotov A. B., Sal'nikova E. B., Korish E. H., Larionov A. N., Anisimova I. V., Bazikov N. S. The Early Precambrian Metamorphic Events in Eastern Sarmatia // Precambrian Research. 2018. V. 311. pp. 1-23. DOI: 10.1016/j.precamres.2018.04.009

15. Савко К. А., Базиков Н. С., Артеменко Г. В. Геохимическая эволюция железисто-кремнистых формаций Воронежского кристаллического массива в раннем докембрии: источники вещества и геохронологические ограничения // Cmpaтиграфия. Геол. Коррелящия. 2015. Т. 23. № 5. С. 3-21. DOI: 10.7868/S0869592X15050063

16. Савко К. А., Кузнецов А. Б., Овчинникова М. Ю. Карбонатные отложения Восточной Сарматии (раннедокембрийская игнатеевская свита, Курский блок): условия образования и палеоконтинентальные корреляции // Стратиграфия. Геол. корреляция. 2020. Т. 28. № 3. С. 3-26. DOI: 10.31857/S0869592Х20030102

17. Савко К. А., Самсонов А. В., Ларионов А. Н., Ларионова Ю. О., Базиков Н. С. Палеопротерозойские граниты А- и Sтипов востока Воронежского кристаллического массива: геохронология, петрогенезис и тектоническая обстановка формирования // Петрология. 2014. Т. 22. № 3. С. 235-264. DOI: $10.7868 / \mathrm{S} 0869590314030054$

18. Савко К. А., Самсонов А. В., Сальникова Е. Б., Котов А. Б., Базиков Н. C. НT/LP Метаморфическая зональность восточной части Воронежского кристаллического массива: возраст, условия и геодинамическая обстановка формирования // Петрология. 2015. Т. 23. № 6. C. 607-623. DOI: $10.7868 / \mathrm{S} 0869590315050040$

19. Terentiev R. A., Savko K. A., Santosh M. Paleoproterozoic evolution of the arc-back-arc system in the East Sarmatian Orogen (East European Craton): zircon SHRIMP geochronology and geochemistry of the Losevo volcanic suite // American Journal of Science. 2017. V. 317. pp. 707-753. DOI: 10.2475/06.2017.03

20. Bogdanova S., Gorbatschev R., Grad M., Guterch A., Janik T., Kozlovskaya E., Motuza G., Skridlaite G., Starostenko V., Taran L. EUROBRIDGE: new insight into the geodynamic evo- 
lution of the East European Craton // European Lithosphere Dynamics. Eds.: Gee, D.G., Stephenson, R.A. Geol. Soc. London Mem. 2006. V. 32. pp. 599-628. DOI: 10.1144/GSL.MEM.2006.032.01.36

21. Савко К. А. Реакционные структуры и эволюция метаморфизма шпинелевых гранулитов Воронежского кристаллического массива // Петрология. 2000. № 2. С. 165-181.

22. Fonarev V. I., Pilugin S. M, Savko K. A., Novikova M. A. Exsolution textures of orthopyroxene and clinopyroxene in highgrade BIF of the Voronezh Crystalline Massif: evidence of ultrahigh-temperature metamorphism // J. Metam. Geol. 2006. V. 24. pp. 135-151. DOI: 10.1111/j.1525-1314.2006.00630.x

23. Савко К. А., Самсонов А. В., Сальникова Е. Б., Котов А. Б., Ларионов А. Н., Кориш Е. Х., Ковач В. П., Базиков Н. С. Мезоархейские тоналит-трондьемит-гранодиоритовые ассоциации Восточной Сарматии: возраст и геологическое положение // Стратиграфия. Геол. корреляция. 2019. Т. 27. № 5. C. 4-18. DOI: $10.31857 / \mathrm{S} 0869-592 \mathrm{X} 2754-18$

24. Савко К. А., Пилюгин С. М., Новикова М. А. Минералогия, фазовые равновесия и условия метаморфизма пород неоархейской железисто-кремнистой формации в пределах Тарасовских аномалий // Вестник Воронежского государственного университета. Серия: Геология. 2004. № 2. С. 111-126. URL: http://www.vestnik.vsu.ru/pdf/heologia/2004/02/savko_ka.pdf (дата обращения: 31.08.2020).

25. Савко К. А., Самсонов А. В., Ларионов А. Н. Мезоархейские кислые вулканиты Курского блока, Воронежский кристаллический массив: состав, возраст и корреляции с Украинским щитом // Докл. АН. 2019. Т. 486. № 6. С. 718-722. DOI: $10.31857 /$ S0869-56524866718-722

26. Larionov A. N., Andreichev V. A., Gee D. G. The Vendian alkaline igneous suite of northern Timan: ion microprobe $\mathrm{U}-\mathrm{Pb}$ zircon ages of gabbros and syenite // The Neoproterozoic Timanide Orogen of Eastern Baltica. Eds. Gee D.G., Pease V.L. Geol.
Soc. London Mem. 2004. V. 30. pp. 69-74. DOI: 10.1144/GSL.MEM.2004.030.01.07

27. Steiger R. H., Jäger E. Subcomission of geochronology: convention of the use of decay constants in geo- and cosmochronology // Earth Planet. Sci. Lett. 1976. V. 36. No. 2. pp. 359-362. DOI: $10.1016 / 0012-821 X(77) 90060-7$

28. Stacey J. S., Kramers I. D. Approximation of terrestrial lead isotope evolution by a two-stage model // Earth Planet. Sci. Lett. 1975. V. 26. No 2. pp. 207-221. DOI: 10.1016/0012821X(75)90088-6

29. Ludwig K. SQUID 2: A User's Manual, rev. 12 Apr, 2009. Berkley Geochron. Ctr. Spec. Pub. 5. 2009. 110 p. URL: http://www.bgc.org/isoplot_etc/squid/SQUID2_5Manual.pdf (дата обращения: 31.08 .2020 ).

30. Jackson S. E., Norman J. P., William L. G., Belousova E. A. The application of laser ablation-inductively coupled plasmamass spectrometry to in situ $\mathrm{U}-\mathrm{Pb}$ zircon geochronology // Chem. Geol. 2004. V. 211. pp. 47-69. DOI: 10.1016/j.chemgeo.2004.06.017

31. Condie K. C. Chemical composition and evolution of the upper continental crust: contrasting results from surface samples and shales // Chem. Geol. 1993. V. 104. pp. 1-37. DOI: 10.1016/0009-2541(93)90140-E

32. Taylor S. R., McLennan S. M. The chemical evolution of the continental crust // Reviews Geophys. 1995. V. 33. pp. 241-265. DOI: $10.1029 / 95 R G 00262$

33. Пилюгин С. М., Фонарев В. И., Савко К. А. Ультравысокие $\left(\geq 1000^{\circ} \mathrm{C}\right)$ температуры метаморфизма метапелитов Воронежского кристаллического массива (Курско-Бесединский гранулитовый блок) по данным полевошпатовой термометрии// Докл. АН. 2009. Т. 424. № 5. С. 660-663. URL: https://www.elibrary.ru/item.asp?id=11687871 (дата обращения: 31.08.2020). 


\title{
Age and Lu-Hf isotope systematics of zircon from metapelite granulites of the Kursk-Besedino Domain: evidence of the Paleoarchean crust within the Kursk Block of Sarmatia
}

\author{
(C) 2020 K. A. Savko ${ }^{1,2 凶}$, A. V. Samsonov ${ }^{3}$, M. V. Chervyakovskaya ${ }^{4}$, \\ E. Kh. Korish ${ }^{1}$, A. N. Larionov ${ }^{5}$, N. S. Bazikov ${ }^{1}$ \\ ${ }^{1}$ Voronezh State University, 1 Universitetskaya pl, Voronezh 394018, Russian Federation \\ ${ }^{2}$ Russian State University of Geological Prospecting, Stary Oskol branch, \\ 14/13 Lenina st., Stary Oskol 309514, Russian Federation \\ ${ }^{3}$ Institute of Geology of Ore Deposits, Petrography, Mineralogy and Geochemistry of the \\ Russian Academy of Sciences, 35 Staromonetny per, Moscow 119017, Russian Federation \\ ${ }^{4}$ Zavaritsky Institute of Geology and Geochemistry of the Ural Branch of the Russian Academy \\ of Sciences, 15 Vonsovskogo st., Ekaterinburg 620016, Russian Federation \\ ${ }^{5}$ Centre of Isotopic Research of A.P. Karpinsky Russian Geological Research Institute \\ (VSEGEI), 74 Sredny pr., Saint-Petersburg 199106, Russian Federation
}

\begin{abstract}
Introduction: In the southern segment of the East European Craton (Sarmatia), the Paleoarchean crust has long been known on the Ukrainian Shield. In the eastern part of Sarmatia (the Kursk Block), the Oboyan complex rocks were belonged to the Early Archean, despite the absence of precise isotope age dating. Sm-Nd and LuHf isotopic data suggest that the Kursk Block comprises rocks with a Paleoarchean crustal prehistory. The aim of our research is to reveal the episodes of the Paleoarchean crust growth based on isotopic U-Pb dating and isotopic Lu-Hf systematics of zircon from metapelite granulites of the Kursk-Besedino Domain.

Methodology: The age and Lu-Hf isotopic composition of zircon from metapelitic granulites of the Kursk-Besedino domain was determined, as well as the content of petrogenic, minor, and rare elements in the rocks.

Results and discussion: Different ages of the zircon overgrowths and cores have been determined. The outgrowths age is about $2.8 \mathrm{Ga}$ and is interpreted as the age of granulite metamorphism. The Paleoarchean ages were determined in the zircon cores cluster at: $3535 \pm 13,3464 \pm 9$, and 3334-3384 Ma, apparently recording episodes of crustal growth and indicating the heterogeneous nature of the provenance source. Although the Lu-Hf isotope system in zircon shows wide variations in the Hf isotopic composition, all $\mathrm{T}_{\mathrm{Hf}}(\mathrm{DM})$ model ages are Paleoarchean, Eoarchean, and even Hadean. The Paleoarchean sediments represented by immature pelites, psammites apparently deposited in marine basins. Their provenance sources were mainly Paleoarchean felsic rocks.

Conclusion: The Paleoarchean crust comprised an older tonalite-trondhjemite-granodiorite basement, covered by volcanic-sedimentary units of pelites, psammites, chemogenic banded iron formations, and injected with basite sills. Such a supracrustal association suggests their formation in a passive margin setting. These rocks were transformed into orthogneisses, metapelite and mafic granulites of the Kursk-Besedino Domain as a result of ca. $2.8 \mathrm{Ga}$ metamorphsm. U-Pb zircon dating of metapelite granulites, permitted recognition of several episodes of crustal growth: 3535-3556, 3464-3472 and 3334-3384 Ma. The zircons have been
\end{abstract}

\footnotetext{
Konstantin A. Savko, e-mail: ksavko@geol.vsu.ru
} 
derived from fragments of the Paleoarchean nucleus of Sarmatia that had a long-lasting crustal prehistory with Eoarhean and even Hadean sources of matter. Zircons provenance source of the third, younger group, is unbeknown, though its age limits a time of the metapelite protolith deposition.

Keywords: Kursk Block, isotope taxonomy, granulites, Paleoarchean

Funding: This work was supported by the RFBR projects No. 19-05-00159 and RSF No. 16-18-10283 and the IGEM RAS state assignment "Petrology and mineralization of magmatism of intraplate and postorogenous environments: the role of lithospheric and asthenospheric sources in the formation of melts".

For citation: Savko K. A., Samsonov A.V., Chervyakovskaya M. V., Korish E. Kh., Larionov A. N., Bazikov N. S. Age and Lu-Hf isotope systematics of zircon from metapelite granulites of the Kursk-Besedino Domain: evidence of the Paleoarchean crust within the Kursk Block of Sarmatia. Vestnik Voronezhskogo gosudarstvennogo universiteta. Seriya: Geologiya $=$ Proceedings of Voronezh State University. Series: Geology, 2020, no. 3. pp. 30-44. DOI: https://doi.org/10.17308/geology.2020.3/3007

\section{REFERENCES}

1. Shcherbak N. P., Artemenko G. V., Lesnaya I. M., Ponomarenko A. N. Geokhronologiya rannego dokembriya Ukrainskogo shchita. Arkhei [Geochronology of Ukrainian Shield early Precambrian. Archaean]. Kiev, Naukova dumka, 2005. 243 p. (in Russ.).

2. Bibikova E., Claesson S., Fedotova A., Artemenko G., Ilyinsky L. Early Archean crust of the Middle Dnepr and Azov Domains, Ukrainian shield - evidence from ages of detrital zircons in Mesoarchean greenstone belts. American Journal of Science, 2010, vol. 310, pp. 1595-1622. DOI: $10.2475 / 10.2010 .13$

3. Claesson S., Artemenko G., Bogdanova S., Shumlyanskyy L. Archean Crustal Evolution in the Ukrainian Shield. Earth's oldest rocks, second edition. Eds: Martin J. van Kranendonk, Vickie Bennett, Elis Hoffmann. Amsterdam, Elsevier, 2018. pp. 837-854. DOI 10.1016/B978-0-444-63901-1.00033-2

4. Savko K. A., Kotov A.B., Sal'nikova E. B., Korish E. Kh., Pilugin S. M., Artemenko G. V., Korikovskii S. P. The Age of Metamorphism of Granulite Complexes of the Voronezh Crystalline Massif: The Monazite U-Pb Geochronology. Doklady Earth Sciences, 2010 vol. 435, no. 2, pp. 1575-1580. DOI: 10.1134/S1028334X10120056 5. Bibikova E. V., Bogdanova S. V., Gorbatschev R., Claesson S., Kirnozova T. I. Isotopic age, nature and structure of the Precambrian crust of Belarus. Stratigraphy and Geological Correlation, 1995, vol. 3 , no. 6, pp. 591-601.

6. Terentiev R. A., Savko K. A., Santosh M., Petrakova M. E., Korish E. H. Paleoproterozoic granitoids of the Don terrane, East-Sarmatian Orogen: age, magma source and tectonic implications. Precambrian Research, 2020, vol. 346, 105790. DOI: 10.1016/j.precamres.2020. 105790

7. Artemenko G. V., Shvaika I. A., Tatarinova E. A. Paleoarkheiski vozrast ul'trametamorficheskikh plagiogranitov KurskoBesedinskogo bloka (Voronezhskii kristallicheskii massiv) [Paleoarchean age of the ultrametamorphic plagiogranites of the KurskBesedino Block (Voronezh Crystalline Massif). Geologichnyi zhur nal, 2006, no. 1, pp. 84-87. (in Russ.).

8. Shchipansky A. A., Samsonov A. V., Petrova A. Yu., Larionova $\mathrm{Yu}$. O. Geodynamics of the eastern margin of Sarmatia in the Paleoproterozoic. Geotectonics, 2007, vol. 41, no. 1, pp. 38-62. DOI $10.1134 / \mathrm{S} 0016852107010050$

9. Korish E. Kh., Savko K. A., Samsonov A. V., Chervyakovskaya M. V. Paleoprotherozoic diorites of the Trosnyansky Massif within the Kursk Block of Sarmatia: U-Pb age, isotope systematic and sources of metls. Vestnik Voronezhskogo gosudarstvennogo universiteta. Serija: Geologija = Proceedings of Voronezh State University. Series: Geology, 2020, no. 1, pp. 87-99. DOI: 10.17308/geology.2020.1/2517 (in Russ.).

10. Savko K. A., Samsonov A. V., Bazikov N. S., Kozlova E. N. Paleoproterozoiskie granitoidy Tim-Yastrebovskoi struktury Voronezhskogo kristallicheskogo massiva: geokhimiya, geokhronologiya $i$ istochniki rasplavov [Palaeoproterozic granitoids of the Tim-Yastrebovskaya structure, Voronezh Crystalline Massif: Geochemistry, geochronology, and melt sources]. Vestnik Voronezhskogo gosudarstvennogo universiteta. Serija: Geologija = Proceedings of Voronezh
State University. Series: Geology, 2014, no. 2, pp. 56-78. URL: http://www.vestnik.vsu.ru/pdf/heologia/2014/02/2014-02-09.pdf (accessed: 31.08 .2020 ). (in Russ.).

11. Savko K. A., Kholina N. V., Samsonov A. V., Korish E. Kh., Chervyakovskaya M. V., Bazikov N. S., Larionov A. N. The petrotype of the Neoarchaean Atamansky granite complex (Kursk block, Sarmatia): geochemistry, geochronology, and isotopic taxonomy. Vestnik Voronezhskogo gosudarstvennogo universiteta. Seriya: Geologiya $=$ Proceedings of Voronezh State University. Series: Geology, 2020, no. 2, pp. 20-43. DOI: 10.17308/geology.2020.2/2857 (in Russ.).

12. Savko K. A., Samsonov A. V., Kholina N. V., Larionov A. N., Zaitseva M. V., Korish E. H., Bazikov N. S., Terentiev R. A. 2.6 Ga high-Si rhyolites and granites in the Kursk Domain, Eastern Sarmatia: Petrology and application for the Archaean palaeocontinental correlations. Precambrian Research, 2019, vol. 322, pp. 170-192. DOI: 10.1016/j.precamres.2019.01.006

13. Savko K. A., Samsonov A. V., Kholin V. M., Bazikov N. S. The Sarmatia megablock as a fragment of the Vaalbara supercontinent: Correlation of geological events at the Archaean-Paleoproterozoic transition. Stratigraphy and Geological Correlation, 2017, vol. 25, no. 2, pp. 123-145. DOI: 10.1134/S0869593817020058

14. Savko K. A., Samsonov A. V., Kotov A. B., Sal'nikova E. B., Korish E. H., Larionov A. N., Anisimova I. V., Bazikov N. S. The Early Precambrian Metamorphic Events in Eastern Sarmatia. Precambrian Research, 2018, vol. 311, pp. 1-23. DOI: 10.1016/j.precamres.2018.04.009

15. Savko K. A., Bazikov N. S., Artemenko G. V. Geochemical evolution of the banded iron formations of the Voronezh crystalline massif in the early Precambrian: Sources of matter and geochronological constraints. Stratigraphy and Geological Correlation, 2015, vol. 23, no. 5, pp. 451-467. DOI: 10.1134/S0869593815050068

16. Savko K. A., Kuznetsov A. B., Ovchinnikova M. Yu. Carbonate deposits of Eastern Sarmatia (Early Precambrian Ignateevskaya suite): sedimentation conditions and paleocontinental correlations. Stratigraphy and Geological Correlation, 2020, vol. 28, no. 3, pp. 326. DOI: $10.31857 / \mathrm{S} 0869592 \mathrm{X} 20030102$

17. Savko K. A., Samsonov A. V., Larionov A. N., Larionova Y.O., Bazikov N.S. Paleoproterozoic A- and S-granites in the eastern Voronezh Crystalline Massif: Geochronology, petrogenesis and tectonic setting of origin. Petrology, 2014, vol. 22, no. 3, pp. 205-233. DOI: 10.1134/S0869591114030059

18. Savko K. A., Samsonov A. V., Sal'nikova E. B., Kotov A., Bazikov N. S. HT/LP metamorphic zoning in the Eastern Voronezh Crystalline Massif: age and parameters of metamorphism and its geodynamic environment. Petrology, 2015, vol. 23, no. 6, pp. 559-575. DOI: $10.1134 / \mathrm{S} 0869591115050045$

19. Terentiev R. A., Savko K. A., Santosh M. Paleoproterozoic evolution of the arc-back-arc system in the East Sarmatian Orogen (East European Craton): zircon SHRIMP geochronology and geochemistry of the Losevo volcanic suite. American Journal of Science, 2017, vol. 317, pp. 707-753. DOI: 10.2475/06.2017.03

20. Bogdanova S., Gorbatschev R., Grad M., Guterch A., Janik T., 
Kozlovskaya E., Motuza G., Skridlaite G., Starostenko V., Taran L. EUROBRIDGE: new insight into the geodynamic evolution of the East European Craton. European Lithosphere Dynamics. Eds.: Gee, D.G., Stephenson, R.A. Geol. Soc. London Mem, 2006, vol. 32. pp. 599-628. DOI: 10.1144/GSL.MEM.2006.032.01.36

21. Savko K. A. Reaction Textures and Metamorphic Evolution of Spinel Granulites in the Voronezh Crystalline Massif. Petrology, 2000, vol. 8, no. 2, pp. 165-181. URL: http://www.geol.vsu.ru/interior/wp-content/uploads/2013/03/Petrology_2_2000.pdf (accessed 31.08.2020).

22. Fonarev V. I., Pilugin S. M, Savko K. A., Novikova M. A. Exsolution textures of orthopyroxene and clinopyroxene in high-grade BIF of the Voronezh Crystalline Massif: evidence of ultrahigh-temperature metamorphism. J. Metam. Geol, 2006, vol. 24, pp. 135-151. DOI: $10.1111 /$ j.1525-1314.2006.00630.x

23. Savko K. A., Samsonov A. V., Sal'nikova E. B., Kotov A. B., Larionov A. N., Korish E. H., Kovach V. P., Bazikov N. S. The Mesoarchean tonalite-trondhjemite-granodiorite associations of Eastern Sarmatia: age and geological setting. Stratigraphy and Geological Correlation, 2019, vol. 27, no. 5, pp. 499-513. DOI: 10.1134/S086959381905006X

24. Savko K. A., Pilyugin S. M., Novikova M. A. Mineralogiya, fazovye ravnovesiya $\mathrm{i}$ usloviya metamorfizma porod neoarkheiskoi zhelezisto-kremnistoi formatsii $\mathrm{v}$ predelakh Tarasovskikh anomalii [Mineralogy, phase equilibria and metamorphic conditions of the Neoarchean banded iron formation rocks from Tarasovsky anomalies] Vestnik Voronezhskogo gosudarstvennogo universiteta. Seriya: Geologiya $=$ Proceedings of Voronezh State University. Series: Geology, 2004, no. 2, p. 111-126. URL: http://www.vestnik.vsu.ru/pdf/heologia/2004/02/savko_ka.pdf (accessed: 31.08.2020). (in Russ.).

25. Savko K. A., Samsonov A. V., Larionov A. N. Mesoarchean silicic volcanics in the Kursk block of the Voronezh Crystalline Massif: Composition, age, and correlations with the Ukrainian Shield Doklady Earth Sciences, 2019, vol. 486, no. 2, pp. 719-723. DOI:

\section{$10.1134 / \mathrm{S} 1028334 \mathrm{X} 19060321$}

26. Larionov A. N., Andreichev V. A., Gee D. G. The Vendian alkaline igneous suite of northern Timan: ion microprobe $\mathrm{U}-\mathrm{Pb}$ zircon ages of gabbros and syenite. The Neoproterozoic Timanide Orogen of Eastern Baltica. Eds. Gee D.G., Pease V.L. Geol. Soc. London Mem, 2004, vol. 30. pp. 69-74. DOI: 10.1144/GSL.MEM.2004.030. 01.07

27. Steiger R. H., Jäger E. Subcomission of geochronology: convention of the use of decay constants in geo- and cosmochronology. Earth Planet. Sci. Lett, 1976, vol. 36, no. 2, pp. 359-362. DOI: 10.1016/0012-821X(77)90060-7

28. Stacey J. S., Kramers I. D. Approximation of terrestrial lead isotope evolution by a two-stage model. Earth Planet. Sci. Lett, 1975, vol. 26, no. 2, pp. 207-221. DOI: 10.1016/0012-821X(75)90088-6

29. Ludwig K. SQUID 2: A User's Manual, rev. 12 Apr, 2009. Berkley Geochron. Ctr. Spec. Pub. 5. 2009. 110 p. URL: http://www.bgc.org/isoplot etc/squid/SQUID2 5Manual.pdf (accessed: 31.08 .2020 ).

30. Jackson S.E., Norman J.P., William L.G., Belousova E.A. The application of laser ablation-inductively coupled plasma-mass spectrometry to in situ U-Pb zircon geochronology. Chem. Geol, 2004, vol. 211, pp. 47-69. DOI: 10.1016/j.chemgeo.2004.06.017

31. Condie K. C. Chemical composition and evolution of the upper continental crust: contrasting results from surface samples and shales. Chem. Geol, 1993, vol. 104, pp. 1-37. DOI: 10.1016/00092541(93)90140-E

32. Taylor S. R., McLennan S. M. The chemical evolution of the continental crust. Reviews Geophys, 1995, vol. 33, pp. 241-265. DOI: 10.1029/95RG00262

33. Pilugin S. M., Fonarev V. I., Savko K. A. Feldspar thermometry of ultrahigh-temperature $\left(\geq 1000^{\circ} \mathrm{C}\right)$ metapelites from the Voronezh Crystalline Massif (Kursk-Besedino granulite block). Doklady Earth Sciences, 2009 , vol. 425 , no. 2, pp. 201-204. DOI: $10.1134 / \mathrm{S} 10283$ 34X09020044
Савко Константин Аркадьевич - д.г.-м.н., профессор, заведующий кафедрой полезных ископаемых и недропользования, Воронежский государственный университет, Воронеж, Российская Федерация; E-mail: ksavko@geol.vsu.ru;

ORCID https://orcid.org/0000-0002-7291-7024

Самсонов Александр Владимирович - д.г.-м.н., г. н. с., Институт геологии рудных месторождений, петрографии, минералогии и геохимии РАН, Москва, Российская Федерация; E-mail: samsonov@igem.ru;

ORCID https://orcid.org/0000-0003-4101-6159

Червяковская Мария Владимировна - младший научный сотрудник, Институт геологии и геохимии им. академика А. Н. Заварицкого Уральского отделения РАН, Екатеринбург, Российская Федерация; E-mail: masha_vuf_91@mail.ru; ORCID https://orcid.org/0000-0002-7074-5433

Кориш Екатерина Хафисовна - ведущий инженер лаборатории комплексных исследований, Воронежский государственный университет, Воронеж, Российская Федерация; Еmail: korish_k@rambler.ru;

ORCID https://orcid.org/0000-0002-6573-1272

Ларионов Александр Николаевич - к.г.-м.н., с. н. с., Центра изотопных исследований ВСЕГЕИ, Санкт-Петербург, Российская Федерация; E-mail: alexander_larionov@vsegei.sp.ru Базиков Николай Сергеевич - к.г.-м.н., доцент кафедры полезных ископаемых и недропользования, Воронежский государственный университет, Воронеж, Российская Федерация; E-mail: nickolasss@yandex.ru;

ORCID https://orchid.org/0000-0002-0847-6498

Авторы прочитали и одобрили окончательный вариант рукописи.
Konstantin A. Savko - PhD, Dr.habil. in Geol-Min., Professor, Head of the Department of Mineral Resources and Mineral Management Studies, Voronezh State University, Voronezh, Russian Federation; E-mail: ksavko@geol.vsu.ru; ORCID https://orcid.org/0000-0002-7291-7024

Alexander V. Samsonov - PhD, Dr.habil. in Geol-Min., Associate Member of the RAS, chief researcher, Institute of Ore Deposits, Petrography, Mineralogy and Geochemistry RAS, Moscow, Russian Fedeartion; E-mail: samsonov@igem.ru; ORCID https://orcid.org/0000-0003-4101-6159

Maria V. Chervyakovskaya - research fellow, Zavaritsky Institute of Geology and Geochemistry of the Ural Branch of the Russian Academy of Sciences, Yekaterinburg, Russian Federation; E-mail: masha vuf 91@mail.ru;

ORCID https://orcid.org/0000-0002-7074-5433

Ekaterina Kh. Korish - leading engineer, Integrated Research Laboratory, Voronezh State University, Voronezh, Russian Federation; E-mail: korish_k@rambler.ru;

ORCID https://orcid.org/0000-0002-6573-1272

Alexander N. Larionov - PhD in Geol-Min., senior research fellow, Centre of Isotopic Research of A. P. Karpinsky Russian Geological Research Institute, Saint Petersburg, Russian Federation; E-mail: alexander_larionov@vsegei.sp.ru

Nikolay S. Bazikov - PhD in Geol-Min., associate professor, Department of Mineral Resources and Mineral Management Studies, Voronezh State University, Voronezh, Russian Federation; E-mail: nickolasss@yandex.ru;

ORCID https://orchid.org/0000-0002-0847-6498

All authors have read and approved the final manuscript. 